\title{
Discours
}

Revue de linguistique, psycholinguistique et

informatique. A journal of linguistics, psycholinguistics

and computational linguistics

$12 \mid 2013$

Varia

\section{A-Bar Scrambling in Repetition in a Case of Mixed Transcortical Aphasia: Hints for the Psychological Reality of the Syntax/Pragmatic Interface}

Ludovico Franco, Elisa Zampieri and Francesca Meneghello

(2) OpenEdition

Journals

Electronic version

URL: http://journals.openedition.org/discours/8762

DOI: $10.4000 /$ discours.8762

ISSN: 1963-1723

Publisher:

Laboratoire LATTICE, Presses universitaires de Caen

Electronic reference

Ludovico Franco, Elisa Zampieri and Francesca Meneghello, «A-Bar Scrambling in Repetition in a

Case of Mixed Transcortical Aphasia: Hints for the Psychological Reality of the Syntax/Pragmatic Interface », Discours [Online], 12 | 2013, Online since 10 July 2013, connection on 30 April 2019. URL http://journals.openedition.org/discours/8762 ; DOI : 10.4000/discours.8762

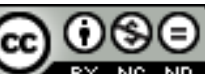

Discours est mis à disposition selon les termes de la licence Creative Commons Attribution - Pas d'Utilisation Commerciale - Pas de Modification 4.0 International. 

Revue de linguistique, psycholinguistique et informatique

\title{
A-Bar Scrambling in Repetition in a Case of Mixed Transcortical Aphasia: Hints for the Psychological Reality of the Syntax/Pragmatic Interface
}

\author{
Ludovico Franco \\ Ca' Foscari University of Venice \\ Elisa Zampieri \\ Ca' Foscari University of Venice \\ Francesca Meneghello \\ IRCCS San Camillo Hospital, Venice
}





\title{
A-Bar Scrambling in Repetition in a Case of Mixed Transcortical Aphasia: Hints for the Psychological Reality of the Syntax/Pragmatic Interface
}

\author{
Ludovico Franco \\ Ca' Foscari University of Venice \\ Elisa Zampieri \\ Ca' Foscari University of Venice \\ Francesca Meneghello \\ IRCCS San Camillo Hospital, Venice
}

\begin{abstract}
The present study deals with sentence repetition in MB, an Italian patient with mixed transcortical aphasia. In preliminary testing, MB spontaneously resisted accurate repetition when presented with sentences featuring morphosyntactic violations (see Davis et al., 1978). $\mathrm{MB}$ also managed to repeat all the proposed phrasal chunks, even in complex sentences. Interestingly, MB tended to move the constituents with the violation (always oblique arguments/adjuncts) to the beginning of the sentence or to another non-canonical position (e.g., dislocating adjuncts immediately before verbs). Thus, he selectively performed "adjunct scrambling". A detailed experimental task confirmed that MB only moved adjuncts or optional complements. Interestingly, most of the scrambled constituents were prosodically-marked by pitch-peaks as contrastive foci. We argue that MB resorts to scrambling as a syntactic strategy. In doing so, he activates projections that encode information related to the interface between syntax and discourse-pragmatics.
\end{abstract}

Keywords: scrambling, mixed transcortical aphasia, syntax-pragmatic interface, repetition

\section{Introduction}

The present study deals with a sentence repetition task in MB, an Italian patient with mixed transcortical aphasia. The term transcortical aphasia identifies a range of syndromes in which the main lesions do not involve the receptive and expressive language areas (Broca's area and Wernicke's area), but rather brain areas in relation with the association cortex (Berthier, 1999). Crucially, patients with transcortical aphasia are able to repeat what they have heard, but have difficulty producing spontaneous speech or understanding sentences. The frequency of transcortical aphasias is very low (Pedersen et al., 2004).

Two major subtypes of transcortical aphasia have been traditionally distinguished (Rubens, 1976; Davis et al., 1978; Alexander et al., I989; Berthier et al., 1991): transcortical motor aphasia and transcortical sensory aphasia, each one presenting rather characteristic clinical manifestations (see Berthier, 1999, for a detailed overview). 
In both major subtypes, however, language repetition is preserved. Moreover, both subtypes can appear simultaneously leading to mixed transcortical aphasia (henceforth, MTA).

Basically, MTA (also known as the "syndrome of the isolation of the speech area") is a rare syndrome in which the patient behaves like a global aphasic but s/he can still repeat (Alexander \& Hillis, 2008).

In patients with MTA, the linguistic output is very reduced (a few words and paraphasias), often quite analogous to global aphasia, although stereotyped utterances are somewhat less usual (Alexander \& Hillis, 2008). Echolalia is often present and repetition is relatively well preserved, with patients who are sometimes able to repeat surprisingly long sentences very accurately without relevant articulatory difficulties (Heilman et al., 1976; Schoenberg \& Scott, 20II). MTA patients may also show features of the completion phenomenon: when stimulated with the beginning of a common phrase, they are sometimes able to repeat what has been said and even to continue the phrase to completion. MTA patients' verbal output, however, often appears mechanical and unwitting (Bogousslavsky et al., 1988).

The most typical lesion in MTA is a very large prefrontal injury with deep extension (Bogousslavsky et al., I988; Rapcsak et al., 1990; Maeshima et al., 1999). In the patient whose case report defined this syndrome, MTA was due to bilateral hypoxic neuronal loss in the arterial border zone (Geschwind et al., 1968; Alexander, 1997). Ischaemic damage in the left border zone de facto causes the same disease. Many cases of MTA are actually due to large anterior thalamic lesions and have involved the anterior, ventrolateral and dorsomedial nuclei (Graff-Radford et al., 1985; Alexander, 1997; Berthier, 1999). Damage to these three nuclei strongly deprives the frontal lobes of thalamic inputs (McFarling et al., 1982). MTA has also been described as a postictal epileptic phenomenon (Yankovsky \& Treves, 2002).

Neurological findings can vary considerably (Berthier et al., 199I). Some patients with MTA show bilateral upper motor neuron paralysis, namely a severe spastic quadriparesis showing bi-hemispheric damage (Nagaratnam \& Nagaratnam, 2000). A visual field defect, usually a right hemianopsia, is present in many cases (Speedie et al., 1984; Pulvermüller \& Schönle, 1993; Davous \& Boller, 1994; Catani \& Ffytche, 2005). Other patients have right hemiplegia and sensory loss (Nagaratnam \& Gilhotra, 1998). MTA is usually found in subjects with severe brain injuries, and an extended set of neurological and neurobehavioural disorders are present (Berthier, 1999).

Recently, MTA has been suggested as striking evidence against the mirror neuron theory of action understanding (cf. Di Pellegrino et al., 1992; Gallese et al., 1996; Rizzolatti \& Arbib, 1998; Rizzolatti \& Craighero, 2004), and more specifically against the motor theory of speech perception (see e.g., Kohler et al., 2002; Galantucci et al., 2006; Lieberman, 2007; Corballis, 2010), which roughly states that phonetic portions in the acoustic speech flow activate previously stored motor commands 
in the brain, which in turn give rise to the perception of discrete speech sounds (Hickok, 2009; Venezia \& Hickok, 2009).

MTA represents a problem for the mirror neuron theory because it is a syndrome that clearly demonstrates the dissociability of motor-speech functions and speech understanding, due to the fact that it is mainly characterized by severe deficits in speech comprehension despite a well-preserved capacity for repeating complex sentences.

Specifically, lesions in the left frontal and posterior parietal regions seem to damage networks playing a role in mapping speech onto conceptual-semantic representations, while leaving the sensory-motor functions supporting repetition of speech intact (Lotto et al., 2009). This dissociation, which is the opposite of the one observed in Broca's aphasics, indicates that - directly counter to the motor theory of speech perception - the preservation of motor speech functions is neither necessary nor sufficient for speech perception.

Furthermore, MTA has been taken as a bint showing that both hemispheres play a role in language control in an unimpaired human brain (Pulvermüller \& Berthier, 2008). While indeed syntactic functions do not seem to resurface in right-hemispheric language processing (Dobel et al., 20or; Moro et al., 200I; Musso et al., 2003; Crosson et al., 2005), residual right-hemispheric language functions at the lexico-semantic level are clearly evident in MTA especially with clinical patterns that involve a complete lesion of the left-perisylvian areas or even hemispherectomy (Pulvermüller \& Schönle, 1993; Mohr et al., 1994; Berthier, 1999; Kastrau et al., 2005).

Our paper analyses the performance in sentence repetition of $\mathrm{MB}$, an Italian right-handed patient with MTA. We focus especially on a "scrambling" phenomenon - which is very unlikely to be found in a repetition task and has not been previously investigated in the literature for the MTA syndrome. We will show below that our patient performs "selective scrambling" when asked to repeat a given sentence.

\section{Scrambling}

Scrambling is still a controversial issue within theoretical linguistics (Sabel \& Saito, 2005). The term scrambling is commonly employed in the literature for the phenomenon of free (or non-canonical) word order (Karimi, 2003). Many languages allow considerable flexibility with respect to word order and scrambling has been investigated in detail for a variety of languages, such as Japanese (Saito, 1985; Saito, 1992; Fukui, 1993), German (Webelhuth, 1990; Müller \& Sternefeld, 1993; Fanselow, 200I), Italian (Frascarelli, 1999; Cardinaletti, 2004; Brunetti, 2009; Samek-Lodovici, 2009), Dutch (Neeleman, 1994), Turkish (Kural, 1992), Spanish (Torrego, 1984; Ordóñez, 1998), French (Obenauer, 1976), Icelandic (Holmberg, 1986; Haider \& Rosengren, 2003), Hindi (Mahajan, 1990 and 1994), Hungarian (Kiss, 1998), Warlpiri 
(Hale, 1983), Jingulu (Pensalfini, 2004), Serbo-Croatian (Bošković, 200I), Russian (Baylin, 1995), and Persian (Karimi, 2005; Adli, 2010).

Scrambling is not a unified phenomenon because it involves a set of syntactic operations within a clause or out of a finite clause (and combinations of them) regarding for example object shift, topicalization/focalization, rightward movement, etc. See the examples [I] to [5] for Persian, adapted from Karimi (2005: I6-18), which show only a partial set of the scrambling operations available for this language.

- Scrambling of the specific object over the subject:

[Ia] pirhan-o Parviz barâ Kimea xarid

shirt-râ P. for K. bought

'As for the shirt, Parviz bought (it) for Kimea.'

Or 'It was the SHIRT that Parviz bought for Kimea.'

[rb] Parviz goft ke pirhan-o Rahjue barâ Kimea xarid P. said that shirt-râ R. for K. bought

Lit. 'Parviz said that, as for the shirt, Rahjue bought (it) for Kimea.'

Or 'Parviz said that it was the SHIRT that Rahjue bought for Kimea.'

- Scrambling of the indirect object over the subject:

[2a] be Sasan hame mi-xand-an

to S. everyone dur-laugh- $3 \mathrm{pl}$

'As for Sasan, everyone laughs at (him).'

Or 'It is at SASAN that everyone laughs.'

[2b] Arezu goft ke be Sasan hame mi-xand-an A. said that to S. everyone dur-laugh-3pl

Lit. 'Arezu said that as for Sasan everyone laughs at (him).'

Or 'Arezu said that it is at SASAN that everyone laughs.'

- Long distance scrambling of the embedded subject:

[3] Kimea pro mi-dun-am ke in film-ro did-e K. dur-know-Isg that this movie-râ saw-3sg

'As for Kimea, I know that (she) has seen this movie.'

- Long distance scrambling of the embedded specific direct object:

[4] in film-ropro mi-dun-am ke Kimea did-e this movie-râ dur-know-Isg that K. saw-3sg

'As for this movie, I know that Kimea has seen (it).' 
- Long distance scrambling of the embedded indirect object:

[5] be Kimea man fekr mi-kon-am ke Arezu un ketâb-ro dâd-e to K. I thought dur-do-isg that A. that book-râ gave-3sg 'To Kimea I think that Arezu has given that book.'

Only a few studies have investigated scrambling-related phenomena within impaired populations. Bastiaanse et al. (2003) studied object scrambling in Dutch Broca's aphasia, showing that, for agrammatic patients, sentences with scrambled word order are more difficult to produce than sentences with basic word order, even when scrambled orders would give pragmatically more acceptable sentences (see also Bastiaanse, 2008). Burchert et al. (2008) studied a group of German agrammatic subjects with a set of elicited canonical sentences without object movement and a set of non-canonical scrambled sentences with object movement. The results of the study show again that Broca's aphasics have a specific problem with the production of scrambled sentences. Further evidence in their study (based on spontaneous speech, elicitation of object relatives, questions and passives) confirms that non-canonical sentences are generally more difficult for agrammatics to produce. Similar findings are reported for a case study with an Italian Broca's aphasic (Garraffa \& Grillo, 2008; Grillo, 2009; Garraffa, 20II). Furthermore, Yarbay Duman et al. (2007) compared the production of simple active sentences in base order (subject-object-verb-SOV) with active sentences in which the object moves over the subject (object-subjectverb - OSV) in Turkish for a group of eight Turkish agrammatic speakers, finding that object scrambling is impaired also in Turkish Broca's aphasics production. A recent investigation of the behaviour of Russian Broca's aphasics (Dragoy \& Bastiaanse, 20IO) shows the same problems for the production of scrambled sentences and, more specifically, the data show that the difficulties in Russian agrammatic speech are related to the number of operations applied to the syntactic structure of a produced sentence (or, from a different perspective, to changing the base-generated position of constituents). Similar impairments in scrambled non-canonical sentences have been detected within a population of Dutch and English Wernicke's aphasics (Bastiaanse \& Edwards, 2004).

In the theoretically oriented literature, scrambling has been analyzed as a stylistic phenomenon or as a syntactic phenomenon (the latter approach roughly subdivided into base generated/flat analyses and movement analyses, as will be shown below). The term was coined by Ross (1967), who originally proposed the rule of scrambling as an operation of the stylistic component and not of (core) syntax. A key point in the contemporary linguistic research on the topic is the field work by Hale (1983; 1992), who addressed free word order in non-configurational languages such as the Australian language Warlpiri, observing that those languages show a whole set of intriguing features such as e.g., pro-drop and discontinuous constituents. Hale originally argued that free word order is a base (parametric) property, namely the result of various base-generated word orders. Interestingly, various researchers on 
Australian languages have frequently observed the inability of speakers to repeat a sentence with the same word order (see Evans \& Levinson, 2009). In particular for Warlpiri, "sentences containing the same content words in different linear arrangements count as repetitions of one another" (Hale, 1983: 5) and "when asked to repeat an utterance, speakers depart from the ordering of the original more often than not" (Hale et al., 1995: I43I).

Conversely, it has been argued that scrambled word orders in other less exotic languages such as German and Japanese are syntactically derived from the basic word order by movement (see, for example, Saito, 1985: for Japanese; and Grewendorf \& Sabel, 1999: for German), although more refined base-generation proposals have been advanced in recent years to explain the free word order phenomenon in these languages as well (see, for instance, Bošković \& Takahashi, 1998: for Japanese; Fanselow, 200I: for German; see also Kiss, 1998: for Hungarian). For those who pursue the movement approach, the analyses of the properties of the relevant movement operation involved in scrambling processes have become a crucial research topic (Sabel \& Saito, 2005), leading, for example, to the proposal of dedicated positions for scrambled constituents within a fine grained/cartographic articulation of syntactic projections (see Rizzi, 1997 and 2006; Rizzi \& Shlonsky, 2007; or the extremely articulated/layered proposal of Benincà \& Poletto, 2004). See [6] for a sketch of Rizzi's (1997) original proposal, where the author motivates the "split" of the complementizer category (C) based on the observation that more than one constituent can be fronted to $\mathrm{C}$, and, in particular, that a series of fronted constituents of various kinds (e.g., topics, foci, etc.) show a hierarchical ordering relative to each other:

\section{[6] Force $>$ (Top) $>$ (Foc) $>$ Fin}

The highest node (Force) is dedicated to clause-typing operators and, in embedded sentences, finite complementizers like English that. Force acts as an interface to higher contexts (e.g., discourse or matrix clauses). The lower node Fin(iteness) hosts non-finite complementizers like English for and acts as an interface to the propositional tense phrase (TP)/inflectional phrase (IP) in its scope ${ }^{1}$.

Within the Minimalist Program (Chomsky, 1995 and 2000), it is assumed that the core syntactic computational system has two interfaces, the conceptual-intentional and the articulatory-perceptual, and within this contemporary framework of research, it is still debated whether scrambling is an operation in the core syntax or if it is a stylistic rule that falls outside of core syntax. Under the minimalist assumption that movement exclusively applies to check morphological features (Movement as Last Resort), there should be a syntactic trigger for this scrambling that could be

1. In [6], as indicated by the brackets, topics and foci are optional. They are sandwiched between Force and Finiteness. Thus, the topic/focus field can be inactivated and the layered complementizer phrase (CP) may be "syncretized" into an un-split C. 
analyzed as a feature-driven movement operation, caused either by an EPP (Extended Projection Principle)-/scrambling-feature (Karimi, 2005) or by a topic-/focus-feature. Base-generation analyses, in contrast, consider that the phenomenon is inherently optional (hence, not triggered) a priori: different word orders obtain as different choices for the base structure are made (Sabel \& Saito, 2005).

However, these differences in the interpretation of scrambling for various kinds of languages, probably suggest that free word order phenomena are not a homogeneous phenomenon and that there is no univocal syntactic macro-parameter responsible for the absence/presence of the phenomenon (see Baker [200I] for the description of different types of free word order languages, e.g., configurational and non-configurational languages, and Pensalfini [2004] for a convincing analysis of scrambling applied to Jingulu, an Australian language within the paradigm of Distributed Morphology for which see Halle and Marantz [1993]). Detailed examinations and comparisons of specific languages would be necessary to discover the inner sources of the scrambling phenomenon. An example of the differences concerning the scrambling phenomenon that can be found among natural languages is given with respect to the locality restrictions applied on it: scrambling out of finite clauses is possible in languages such as Hindi, Korean, Japanese, Persian, Serbo-Croatian and Russian, but not in Polish, German, Dutch, and Warlpiri (Sabel \& Saito, 2005). Furthermore, languages such as German, Dutch and Warlpiri have obligatory overt $w h$-movement and very restricted $w h$-scrambling. In this regard, these languages behave differently if compared e.g., with Persian Hindi, Korean Japanese, and Serbo-Croatian (see Grewendorf \& Sabel, 1999; Karimi, 2005, for relevant discussion).

Finally, a crucial fact to be mentioned here is that, from a descriptive viewpoint, scrambling often applies in order to achieve information structure effects. Under this analysis, the scrambled element represents a Topic or a Focus, enhancing/ triggering the syntax-pragmatic interface (Rizzi, 1997; Bocci, 2004).

\section{Method and materials}

\subsection{Preliminary observation}

The aim of this study was to examine the repetition abilities of an Italian speaker with MTA. Individuals with Transcortical aphasia have often been observed (in English) to regularize minor syntactic violations when asked to repeat ungrammatical sentences (Davis et al., 1978). Our first aim was to verify whether this observation held for Italian. We administered a repetition task including some ungrammatical sentences, with errors concerning simple and complex prepositions with incorporated articles (e.g., errors in phi-features, substitutions, etc.). The patient was instructed to repeat every sentence exactly as produced by the examiner. As expected, $\mathrm{MB}$ tended to correct the grammatical errors contained in the sentences (e.g., correcting the 
preposition), as shown in Table I. The ungrammatical sentences of our preliminary task are reported in Appendix A.

\begin{tabular}{|l|l|l|l|}
\hline & $\begin{array}{l}\text { Total number of } \\
\text { sentences }\end{array}$ & Regularizations \\
\hline & & Number & Percentage \\
\hline $\begin{array}{l}\text { Ungrammatical } \\
\text { sentences }\end{array}$ & 59 & 23 & 39 \\
\hline
\end{tabular}

Table 1. Preliminary repetition task. MB's performance with ungrammatical sentence

This result was predicted as it had already been observed for the English language. Nevertheless, a previously unobserved pattern emerged during this experiment. We noticed that MB tended to selectively move (scramble) some constituents of the sentence. Specifically, MB managed to repeat all the proposed phrasal chunks, even in the case of complex and long sentences, but he often recombined the to-be-repeated word order by moving a constituent either to the beginning of the sentence or to another non-canonical position (cf. Belletti, 2004 and 2005; e.g.,

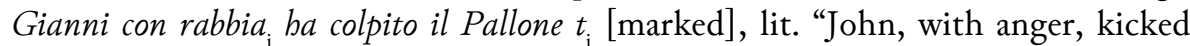
the ball" vs. Gianni ba colpito il Pallone con rabbia [unmarked], "John kicked the ball with anger").

Interestingly, he most often moved the constituent in which an anomaly had been inserted. Moreover, once he had moved the element, he was able to reorganize the sentence into a grammatically acceptable result.

An analysis of MB's repetitions revealed that he only moved adjoined constituents or (oblique) optional complements. This fact explains the high number of errors on ungrammatical sentences. Anomalies, in fact, only concerned prepositional phrases, which, in Italian, are likely to introduce adjuncts or oblique complements. Observing the few grammatical sentences which had been used as distracters, we noticed that scrambling was also present, albeit in a minor proportion.

To better investigate this preliminary observation, we created a list of sentences to be repeated composed of grammatical sentences only. As we will show, the patient performed again a very high percentage of scrambling operations with optional constituents. In Table 2 we report data concerning the preliminary task, showing the percentage of scrambling in ungrammatical and grammatical sentences.

\begin{tabular}{|l|l|}
\hline Sentences & Percentage of scrambling of adjuncts \\
\hline Ungrammatical sentences & $43 \cdot 3$ \\
\hline Grammatical sentences & 20 \\
\hline
\end{tabular}

Table 2. Preliminary task. Scrambling in grammatical vs. ungrammatical sentences 


\subsection{Experimental procedures}

\subsubsection{The patient}

$\mathrm{MB}$ is a 49 -year-old right-handed man with 13 years of education. He is Italian, living in the province of Venice. He worked as a broker. In February zoro he suffered a stroke that caused a very extended lesion of the left parietal and frontal (including mesial frontal) lobes, the insula, the dorsal and ventral striatum and the anterior thalamus. MB also has a quite pronounced cerebral atrophy (see Tiw MRI brain images in Figure I). His language functions were evaluated via batteries of both standard and non-standard tests (the Italian version of the Aachener Aphasie Test - AAT, Luzzatti et al., 1996; Batteria per Analisi Deficit Afasici - BADA, Miceli et al., 1994). The neuropsychological assessment revealed, in general, that MB had great difficulties with complex tasks and many problems in obeying rules. On the Raven P.M. 1947 Test, which measures general non-verbal intelligence, MB's performance was $(2 \mathrm{I} / 36)$. In the Visual Search Test which measures attention, MB was above the cutoff for normal performance (40/60; cutoff score 30), while his score on the Corsi Block-Tapping Test which measures Spatial Span was 4, just below the lower normal limits.

Hence, MB showed deficits especially affecting attentive and executive functions while he had no problems in logical and deductive reasoning. His short-term memory (both verbal and visuo-spatial) was preserved while his working memory was impaired, as shown by the results of the Digit Span Test (Orsini et al., 1987): the Digits Forward Test score was 8; the Digits Backward Test score was 2.

MB's spontaneous language production was heavily impaired. It was impossible to collect samples of spontaneous speech because of his inability to spontaneously produce more than one or two words, making his spontaneous speech highly nonfluent. At the time of the present investigation (February 20II), the AAT showed that $\mathrm{MB}$ was moderately impaired on naming tasks (4I/I20 correct answers). The main problems were with colours ( $7 / 30$ correct answers) and compound words $(\mathrm{I} / 30$ correct answers) while objects were retrieved more easily (2I/30 correct answers). The picture description was almost impossible for $\mathrm{MB}$, given his non-fluent aphasia ( $2 / 30$ correct answers). Note that, in the AAT, picture description is considered a naming task; hence MB's naming ability was severely impaired. Nevertheless, this result could depend on his difficulties in spontaneously producing sentences. A similar deficit emerged with the BADA, where both the elicited and the free picture description were impossible for $\mathrm{MB}$ who did not manage to produce any correct answers. Repetition was only mildly impaired both in AAT (132/150 correct answers) and BADA (repetition of words $9 / 45$ errors and repetition of non-words $8 / 35$ errors). Both words and non-words were correctly repeated and only a few errors were detected in sentence repetition (in the AAT, 19/30 correct answers). AAT showed a moderate impairment in both aural and written comprehension (74/120 correct answers); his difficulties were equally distributed among tasks 
including words and sentences. This kind of deficit, however, was not caused by morpho-syntactic impairments, as proved by MB's good performance on both the grammatical judgement task ( $4 / 48$ errors) and the grammatical comprehension task (8/60 errors) of the BADA battery. Written language posed many problems for $\mathrm{MB}$, who showed some difficulties in reading words (22/30 correct answers) and was incapable of taking dictation ( $\mathrm{o} / 30$ correct answers).

In conclusion, MB's linguistic deficit affected above all his spontaneous speech. The deficit also emerged even if a visual aid was given to him (e.g., a picture to be described). Moreover, he could not write at all, and he showed some difficulties in the reading tasks, whereas his morpho-syntactic abilities were quite well preserved as well as his capacity for repeating words, non-words and, with some very mild difficulties, sentences.

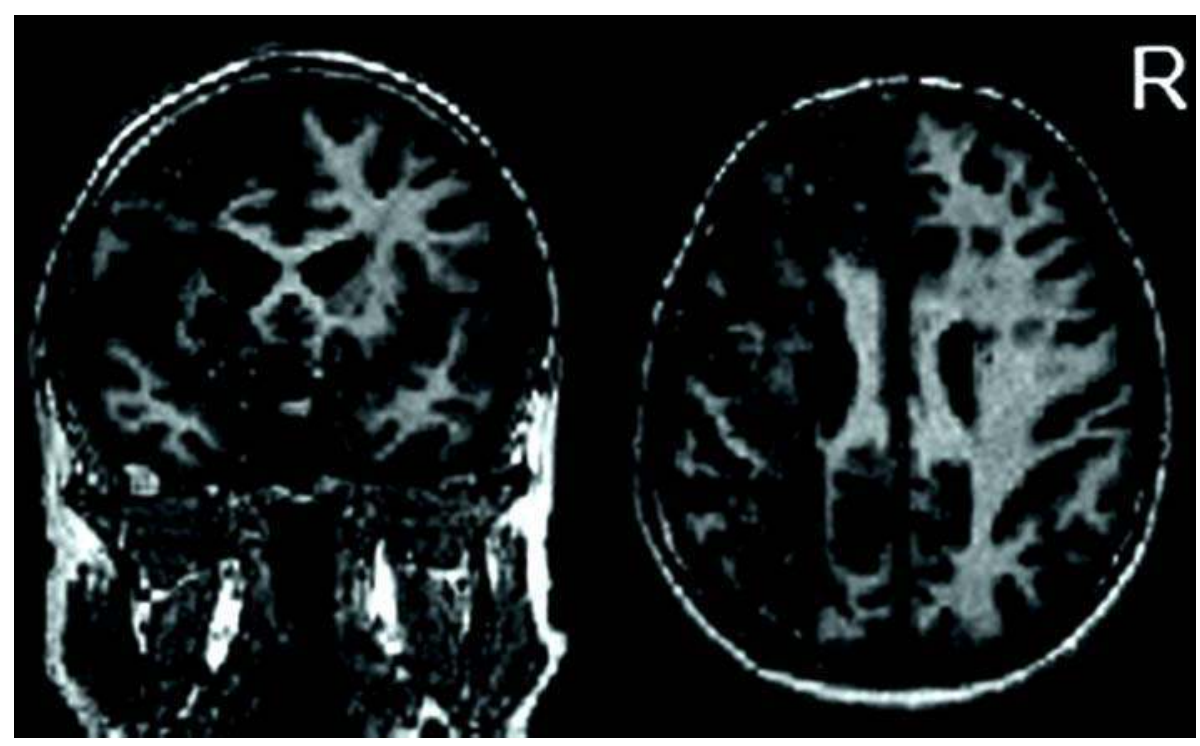

Figure 1. Axial and coronal T1w images of MB's brain

\subsubsection{Materials}

Our repetition task included, in all, 234 sentences. To verify our previous observation we prepared three types of sentences:

(a) I2O sentences without adjuncts or optional oblique complements;

(b) IO4 sentences containing adjuncts or optional oblique complements;

(c) a few sentences (Io) in which a constituent had already been scrambled.

We used both short and long sentences as well as many different balanced syntactic constructions in all three groups of items. In this way the only difference 
between sentences pertaining in particular to group (a) and (b) was the presence or the absence of optional constituents. A first observation was that only adjuncts or complements, whose scope covers the entire sentence, were scrambled by MB. Thus, optional constituents specifically related to a single element of the clause (e.g., modifiers of a noun phrase) were inserted in the first group of items.

We provide below a detailed list of all the sentences (see Appendix B for the complete sets of stimuli) included in the three groups of items (translations are to be considered literally, given the presence of some constructions which do not exist in English):

Set (a) included:

(i) Simple sentences with transitive verbs (lo specchio riflette la mia imagine - lit. "the mirror reflects the my image").

(ii) Copular constructions (la medicina non è una scienza esatta - lit. "the medicine is not a science exact").

(iii) Passive sentences (la porta è stata chiusa dal vento - lit. "the door was closed by the wind").

(iv) Pronominal sentences (la macedonia si mangia col cucchiaino - lit. "the fruit salad [impersonal clitic] eats with the spoon").

(v) Complex sentences (hypothetical, temporal or infinitival subordinates, e.g., anche se piangi non ti prenderò in braccio - lit. "even if cry I won't pick you up").

(vi) Sentences with unaccusative verbs (è uscito un film interessante - "an interesting film is come out").

(vii) Sentences with verbs that take three arguments, the third of which is obligatory to ensure the grammaticality of the sentence (Gianni porta sempre suo figlio allo stadio - "John always takes his son to the stadium").

Set (b) included:

(i) Sentences with transitive verbs (i bambini aspettano l'estate con impazienza - lit. "the children are waiting for the summer with impatience").

(ii) Copular constructions (il ventilatore è acceso in salotto - "the ventilator is working in the living room").

(iii) Pronominal sentences (Luca si è tagliato con la carta - "Luca cut himself with the paper").

(iv) Sentences with unaccusative verbs (il bicchiere è caduto dalla tavola - "the glass is fallen from the table").

(v) Sentences with verbs that take three arguments, the third of which is not obligatory to ensure the grammaticality of the sentence, but also including a further adjunct (la compagnia telefonica spedirà una lettera il mese prossimo ai turisti francesi - "the telephone operator will send a letter the next month to French tourists").

Set (c) included:

(i) Sentences in which a constituent had already been scrambled, e.g., left dislocated (il ladro lo ba arrestato il commissario - lit. "the thief, him has arrested the chief of police"). 


\subsection{The repetition task}

\subsection{Analysis} analyzed. foci.

\section{Results}

Our tasks were not wearying for $\mathrm{MB}$, given that he had no problems in repeating and that his verbal memory was preserved. Despite this, items were randomly organized and presented to the patient in 5 separate sessions, each including about 45 sentences and lasting a few minutes. The administration of a limited number of items at a time was necessary to avoid the collection of many incomplete answers, since when $\mathrm{MB}$ began to perceive his errors, he tended to interrupt his repetition after he had pronounced one or two words of the scrambled constituent.

The patient was asked to faithfully repeat every sentence as soon as he had heard it from the examiner. Sentences of sets (a), (b) and (c) were matched for length/ number of words, stress pattern and syntactic complexity.

Every session was digitally audio-recorded and answers were both transcribed at the moment and subsequently checked. The examiner presented the stimuli to the patient twice only if the patient asked him to do so.

Only repetitions exactly matching the target sentence were considered correct. Errors were classified with respect to whether they contained scrambled elements. Moreover the different types of constituents which had been moved were separately

MB's production was also analyzed using Praat v. 5.3.2I (Boersma, 200I), a scientific software program for the analysis of speech in phonetics/phonology. Since MB tended to move adjuncts in non-canonical positions, which, in Italian, are normally occupied by prosodically marked (e.g., focalized) elements, we used Praat to check whether MB's scrambled sentences were prosodically marked as

As expected, $\mathrm{MB}$ produced in general a high number of right answers, confirming that his capacity of correctly repeating was quite well preserved. See Table 3 below.

\begin{tabular}{|l|l|}
\hline Sentences & Percentage \\
\hline Correct & 80.77 \\
\hline Errors & 19.23 \\
\hline
\end{tabular}

Table 3. General pattern of the experimental set

Despite this fact, a deeper analysis of MB's answers revealed that the distribution of errors changed depending on the type of sentence he was asked to repeat. As shown in Table 4, in fact, the majority of wrong repetitions affected sentences 
which contained adjuncts or oblique optional constituents (no errors were detected with sentences already "scrambled").

\begin{tabular}{|l|l|}
\hline Sentences & Percentage of errors \\
\hline Without optional constituents & 7.5 \\
\hline With optional constituents & 32.69 \\
\hline
\end{tabular}

Table 4. Sentences with optional constituents vs. sentences without optional constituents

Even more interestingly, the qualitative analysis of MB's errors revealed that the canonical word order in sentences without adjuncts or optional complements was hardly ever changed. As shown in Table 5 , only one case of scrambling was detected, while all other errors concerned sporadic omission and substitutions of both lexical and functional elements. We also noticed that the percentage of scrambling was the same as that of all other errors.

\begin{tabular}{|l|l|l|}
\hline $\begin{array}{l}\text { Errors in sentences without optional } \\
\text { constituents }\end{array}$ & Absolute number & $\begin{array}{l}\text { Percentage of total number } \\
\text { of errors }\end{array}$ \\
\hline Non-production & 3 & 33.33 \\
\hline SCRAMBLING & I & II.II \\
\hline Omission of a nominal modifier & I & II.II \\
\hline Adverb omission & I & II.II \\
\hline Article omission & I & II.II \\
\hline Passive to active & I & II.II \\
\hline Subject omission & I & II.II \\
\hline
\end{tabular}

Table 5. Types of errors in sentences without optional constituents

To verify our previous assumption, we also separately analysed sentences including adjuncts strictly modifying a single phrase. As we expected, on a total of I3 sentences, no errors were detected, confirming that MB's deficit selectively affected optional elements, with scope over the entire sentence.

On the other hand, when an optional constituent was present, MB tended to move it to the beginning of the sentence (more frequently) or to another higher non-canonical position (e.g., in a verb phrase [VP] peripheral position within the low IP area, following the insight of Belletti [2004]). Moreover, MB often interrupted the repetition when he realized that his performance was not correct. Consequently, we collected some incomplete answers including only one or two words which should not appear at the beginning of the sentence. We classified these 
answers as "beginning of scrambling". Adding these "beginning of scramble" cases to complete sentences with a scrambled constituent, we obtained an even higher percentage $(70.59 \%)$ of occurrence of the phenomenon under discussion here.

The prosodic analysis performed with Praat revealed that, very surprisingly, in MB's repetitions, a very high percentage (19/22; 86.36\%) of the scrambled constituents in the set (b) received a special prosodic contour, anchored on the last word of the moved phrase, i.e., the moved constituent seems to be informationally treated by our patient as a (contrastive) focus (cf. Benincà et al., 1988; Rizzi, 1997; Bocci, 2004) ${ }^{2}$. In the figures $2 \mathrm{a}-\mathrm{c}$, some examples are provided where Focus peaks are easily recognizable.

When MB did not move any element, he generally managed to correctly repeat the sentences. However, as in the first group of items, we detected some unsystematic errors other than scrambling. In Table 6 we present the complete data concerning the sentences of set (b) including optional constituents.

\begin{tabular}{|l|l|l|}
\hline $\begin{array}{l}\text { Errors in sentences with adjuncts or } \\
\text { optional complements }\end{array}$ & Absolute number & $\begin{array}{l}\text { Percentage of total number } \\
\text { of errors }\end{array}$ \\
\hline Non-production & 2 & 5.88 \\
\hline SCRAMBLING & 22 & $64.7 \mathrm{I}$ \\
\hline Beginning of scrambling & 2 & 5.88 \\
\hline Adjunct omission & $\mathrm{I}$ & 2.94 \\
\hline Omission of a nominal modifier & 3 & 8.82 \\
\hline Verb omission & $\mathrm{I}$ & 2.94 \\
\hline Subject omission & 2 & 5.88 \\
\hline $\begin{array}{l}\text { Adjunction of a quantificational } \\
\text { modifier }\end{array}$ & $\mathrm{I}$ & 2.94 \\
\hline
\end{tabular}

Table 6. Type of errors in sentence with optional constituents

As can be seen, there is a statistically very significant difference between scrambled sentences in the repetition task of set (a) vs. set (b): [I/I2O vs. $22 / \mathrm{IO} 4: \chi^{2}(\mathrm{I})=\mathrm{I} 8.302$; $\mathrm{p}<0.000 \mathrm{I}]$.

2. It is well known that many languages show consistent interactions between prosody and syntax: e.g., languages like Italian or Catalan use word order changes so that particular items that must be in focus can phonologically be accentuated; in such languages, word order changes must accompany accentuation (see Bocci, 2004; Ladd, 2008). 


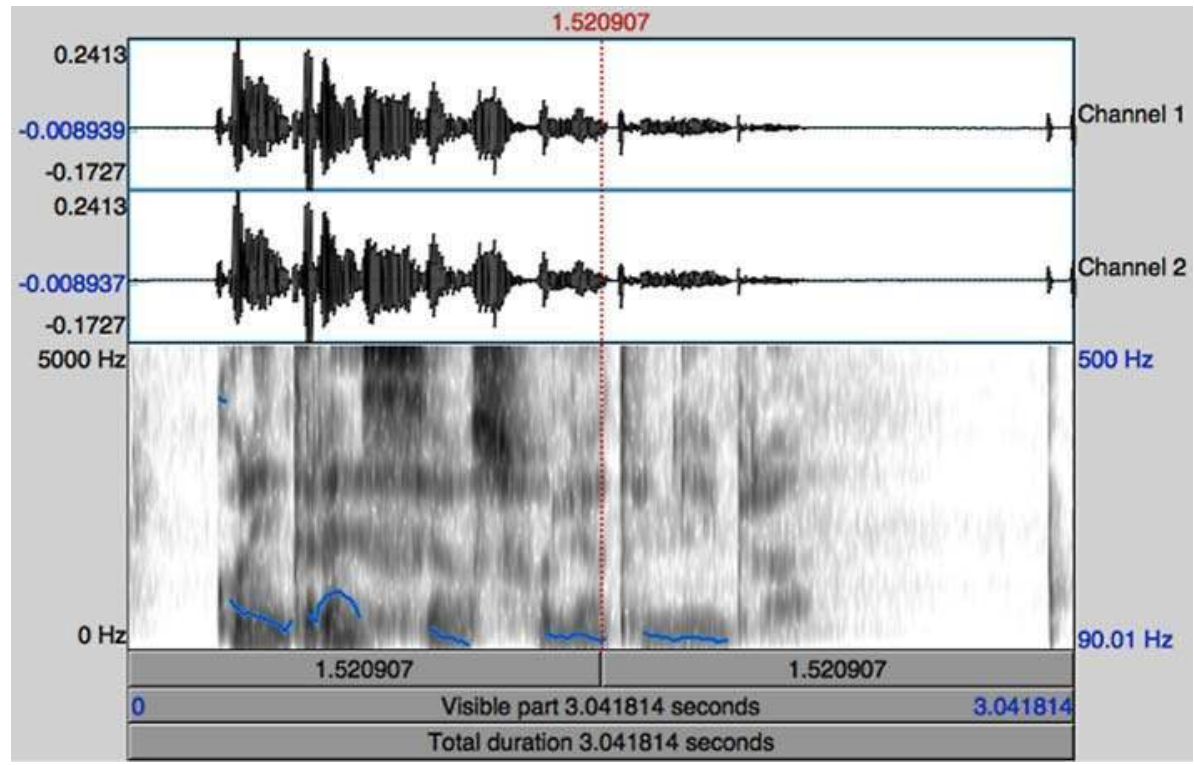

Figure 2a. Phonetic analysis of MB's sentence: con interesse bo sfogliato il libro [target answer: bo sfogliato il libro con interesse, "I have read the book with interest"]

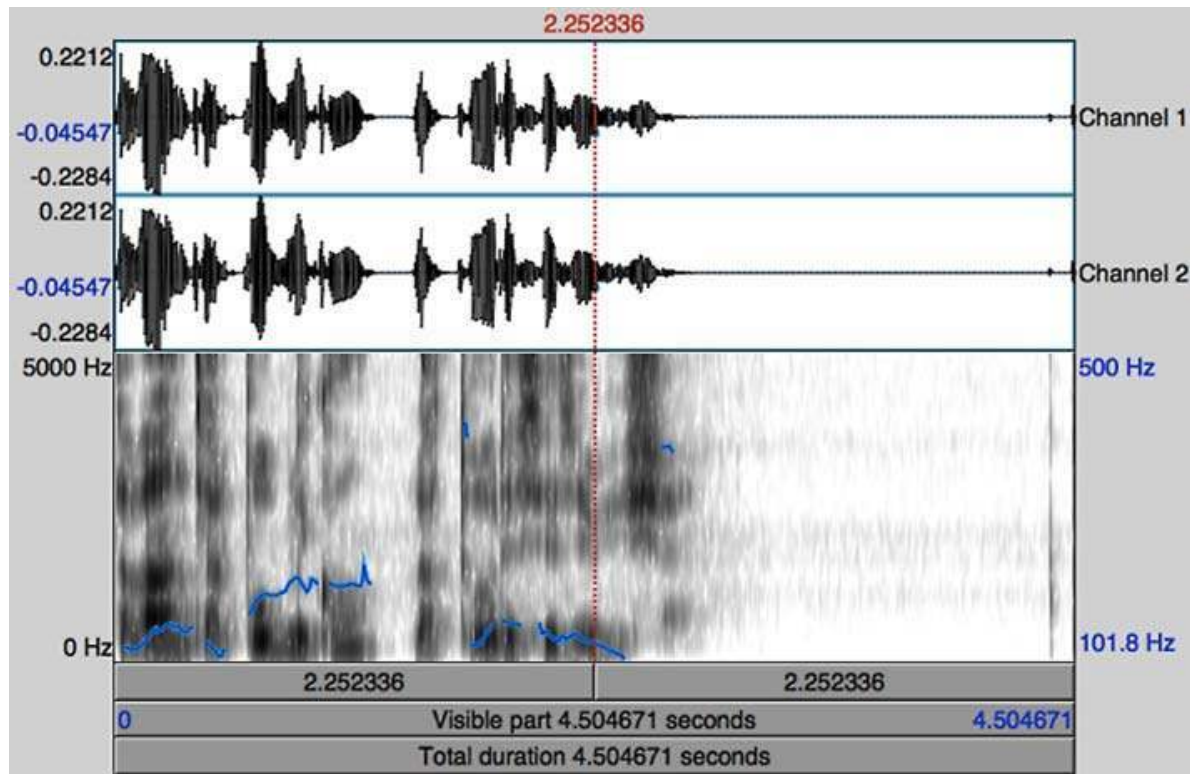

Figure 2b. Phonetic analysis of MB's sentence: davanti al pubblico l'attore si esibisce [target: l'attore si esibisce davanti al pubblico, "the actor performs in front of the audience"] 


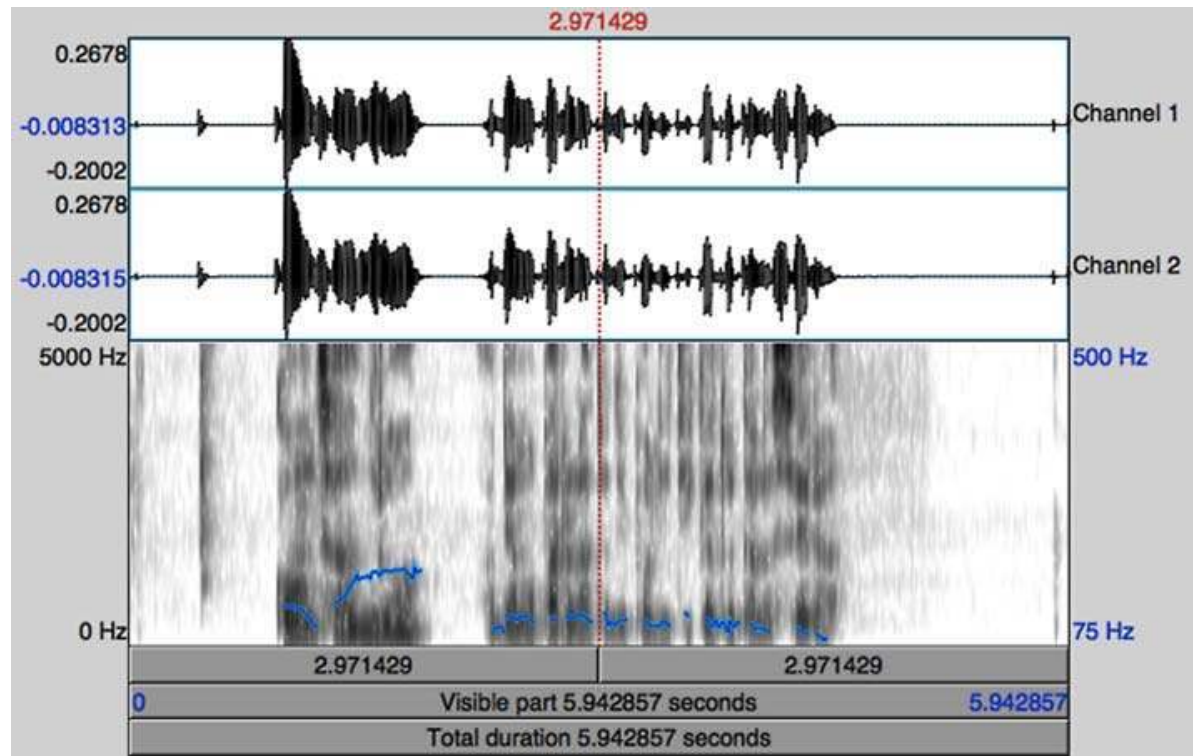

Figure 2c. Phonetic analysis of MB's sentence: con Carlo abbiamo parlato di politica tutta la sera [target: abbiamo parlato di politica tutta la sera con Carlo, "we talked about politics all the evening with Carlo"]

\section{Discussion}

Our study shows that the performance in repetition of a MTA patient is characterized by active recombination/regeneration and not automatic echolalia. It is arguable that $\mathrm{MB}$ resorts to scrambling as a syntactic strategy. In doing so, he activates projections that encode information related to the interface between syntax and discourse-pragmatics. A tentative explanation, grounded within current paradigms of syntactic research, is the following: MB switches on Focus Projections as dummy placeholders in order to lower the processing weight of the core Argument Structure. With this strategy, MB seems to avoid the increase in the computational load of the syntactic derivations. In fact, in sentence processing, argument-structure complexity has been shown to be one of the main factors that influence correct retrieval (see Shapiro et al., 1987; Thompson, 2003).

An alternative explanation suggested by an anonymous reviewer is that adjuncts are prosodically marked and moved leftward because they usually carry new and prominent information, while argument structure is given, as shown for instance in Couper-Kuhlen and Thompson (2008) or Hopper and Thompson (2008). According to this view, this kind of scrambled adjuncts - like extraposed "lexical bundles" (cf. Biber et al., I999) - potentially are "among the routinized resources available to speakers to organize talk in anticipation of upcoming verbal interactions in 
terms of context, temporality, and strategic online management of interactional contingencies" (Hopper \& Thompson, 2008: II6).

In our view, the availability of scrambling as a linguistic strategy in a repetition task in a subject affected by MTA seems to support the idea that scrambled constructions need to be treated as associated with a set of functional projection targets of A-bar movement (along the lines of Rizzi [1997] and subsequent work). In other words, $\mathrm{MB}$ uses dedicated positions in the left periphery of the sentence to retrieve peripheral phrases, relatively far from the core argumental structure of the verb.

This core argument structure in canonical sentences is more resistant to working memory deficits (see Shapiro et al., 1993; Trueswell et al., 1993; Thompson et al., 1997), while optional elements are somewhat weaker/poorer.

$\mathrm{MB}$, as we have said above, has a relatively unimpaired verbal memory, but a poor working memory, which has a crucial influence on the overall performance with syntactic derivations.

More technically, our hypothesis is that MB switches on A-bar positions in a layered CP commonly dedicated to encode clause types, focalized and topicalized items, evidentiality, points of view and so on (Rizzi, I997 and 200I; Cinque, 1999, among others). All of the above mentioned facts are discourse related, and thus items displaced in a layered CP are discourse-determined (this fact also explains the reason why only phrasal adjuncts are moved by $\mathrm{MB}$, while optional modifiers of the noun are correctly repeated following the proposed order).

$\mathrm{MB}$ seems to reverse the perspective: core arguments are licensed and interpreted in canonical A-positions (i.e., $\mathrm{TP}$ and $v \mathrm{P} / \mathrm{AspP}$ ) while the items in the layered $\mathrm{CP}$ are syntax-determined and, therefore, the discourse-determined field is converted into a place in which he conveys modifiers/adjoined constituents ${ }^{3}$.

In other words, it seems to us that adjunction/modification is a very costly operation for $\mathrm{MB}$, who can therefore perform it only very high (left) in the structure because of his marked deficit in working memory. So, once he had first pronounced the weakest element (weakest from the point of view of the working memory buffer) in order to remember it, he uses projections dedicated to scrambled elements, reorganizing the sentence and prosodically marking the moved constituent, with the aim of obtaining a grammatical result.

Thus, MB seems to build up the rest of the sentence once he had (dis)placed the adjunct, taking it as starting point to allow a correct syntactic computation.

3. Very interestingly, when the left periphery of the clause is activated by MB, prosodic marking is necessarily involved, signalling that models such as Cartography (Cinque \& Rizzi, 20ıo) which assume a deep interrelationship among phonology, syntax and pragmatics are on the right track and have psychological reality. Otherwise, MB could have activated the CP field without necessarily marking the intonational contour of the scrambled sentences. 
This fact can be speculatively interpreted as justification for those theoretical models which predict a left to right/top-down parsing (derivation) of human syntax such as the ones proposed by Phillips (2003), Richards (200I) or Chesi (2004) and Bianchi and Chesi (2010). In particular, the prosodic "activations" of MB can be also alternatively explained following a more processing oriented perspective, such as the one pursued by the strictly top-down parsing paradigm of Dynamic Syntax (DS), which roughly assumes that our linguistic parser shows inferential/ anticipatory abilities at each step of a derivation until a complete proposition is achieved (Kempson et al., 200I; Cann et al., 2005) ${ }^{4}$.

Recent work (e.g., Kempson \& Kiaer, 20IO) within the framework of DS has convincingly shown that, in verb-final languages such as Korean or Japanese, the linguistic parser can incrementally build up a structure from the very beginning with the aid of prosody (and Case-marking, see the work by Miyamoto [2002] for Japanese). Without entering into the technical details of DS, as said, a possible alternative hypothesis for our case study could be that MB's scrambling is the consequence of a working memory driven rearrangement of the monotonic structure growth processes from left to right, top down.

\section{Conclusion}

We have presented here the results of a repetition task performed by MB, an Italian man affected by MTA. We have shown that MB resorts to scrambling as a syntactic strategy. In doing so, he arguably activates projections located in the left periphery of the clause that encode information related to the interface between syntax and discourse/pragmatics.

We have argued here that MB's highly reduced working memory span drives him to adopt a strategy of a minimizing chunks in the syntactic module that triggers this unexpected activation of positions encoding information related to the syntax-pragmatics interface (whose reflex is visible by means of the prosodic contour of the scrambled constituent). A possible explanation which draws on contemporary linguistic theory is that $\mathrm{MB}$ activates Focus Projection, which is very unlikely to be found in a repetition task, as a dummy placeholder in order to lower the computational load of the core Argument Structure, due to a marked deficit in

4. DS is a research paradigm that tries to explain how the human parser builds up a syntactic structure incrementally from left to right/top-down in real-time parsing. The main challenge of DS is to arrange how the language-parser can manipulate partial information "at each step of parsing to draw a bigger picture of the meaning of the string as early as possible” (Kiaer \& Kempson, 2005: 2II). The DS framework basically adopts representationalist assumptions about the nature of mind (Fodor, 1983) and assumes that semantic interpretation is given as a structural representation of content, with trees representing predicate-argument structure in which the top node of a tree is decorated with a propositional formula and each dominated node is a subterm of that formula, with type-specifications indicating how the parts combine. 
working memory ${ }^{5}$. In fact, in sentence processing, argument-structure complexity has been shown to be one of the main factors that determine correct retrieval (e.g., Shapiro et al., 1987; Thompson, 2003, among many others).

\section{Acknowledgements}

This article is the result of close collaboration between the first two authors (joint first authorship), whose names are listed in alphabetical order. Dr. Meneghello supervised the clinical research at IRCSS San Camillo Hospital, Venice. For Italian academic purposes, Ludovico Franco takes responsibility for Sections I, 2, 5 and Elisa Zampieri takes responsibility for Sections 3, 4, 6 (but all sections are the result of close cooperation between the two authors). An earlier version of this article was presented at the Academy of Aphasia 49th Annual Meeting (October 2oII), Montreal. We thank the audience for comments and criticism. We would like to thank Paola Benincà, Anna Cardinaletti, Guglielmo Cinque, Rita Manzini, Andrea Marini, Carlo Semenza and two anonymous reviewers of Discours for extremely useful comments. Many thanks to the editors of this issue of Discours, Saveria Colonna and Sarah Schimke, for their support and for their advice concerning the revision process. We also thank Molly McIlwrath for proofreading the manuscript. All errors are our own.

\section{References}

AdLI, A. 20Io. Constraint Cumulativity and Gradience: Wh-Scrambling in Persian. Lingua I2O (9): 2259-2294.

Alexander, M.P. 1997. Aphasia: Clinical and Anatomic Aspects. In T.E. Feinberg \& M.J. Farah (eds.), Behavioral Neurology and Neuropsychology. New York: McGraw-Hill: I33-I5O.

Alexander, M.P. \& Hillis, A.E. 2008. Aphasia. In M.J. Aminoff, F. Boller, D.F. SwaAb, G. Goldenberg \& B.L. Miller (eds.), Neuropsychology and Bebavioral Neurology. Handbook of Clinical Neurology 88. Edinburgh - London - New York: Elsevier: 287-309.

Alexander, M.P., Hiltbrunner, B. \& Fischer, R.S. 1989. Distributed Anatomy of Transcortical Sensory Aphasia. Archives of Neurology 46 (8): 885-892.

BAKer, M.C. 200I. The Atoms of Language: The Mind's Hidden Rules of Grammar. New York: Basic Books.

BastiaAnse, R. 2008. Production of Verbs in Base Position by Dutch Agrammatic Speakers: Inflection versus Finiteness. Journal of Neurolinguistics 2I (2): I04-II9.

Bastiannse, R. \& Edwards, S. 2004. Word Order and Finiteness in Dutch and English Broca's and Wernicke's Aphasia. Brain and Language 89 (I): 9I-I07.

5. Unfortunately, MB cannot be the subject of further testing, but as suggested by an anonymous reviewer, more fine-grained experiments are needed to check the validity of our hypothesis. In particular, in future work on the topic, it will be important to check if - varying the complexity of argument structure - adjuncts are scrambled more in more complex sentences. 
Bastiannse, R., Koekkoek, J. \& Van Zonneveld, R. 2003. Object Scrambling in Dutch Broca's Aphasia. Brain and Language 86 (2): 287-299.

BAYlin, J. 1995. Underlying Phrase Structure and "Short" Verb Movement in Russian. Journal of Slavic Linguistics 3 (I): 13-58.

Belletti, A. 2004. Aspects of the Low IP Area. In L. Rizzi (ed.), The Cartography of Syntactic Structures. Oxford - New York - Auckland: Oxford University Press. Vol. 2: The Structure of CP and IP: I6-5I.

Belletti, A. 2005. Extended Doubling and the VP Periphery. Probus I7 (I): I-35.

BenincÀ, P. \& Poletto, C. 2004. Topic, Focus and V2: Defining the CP Sublayers. In L. Rizzi (ed.), The Cartography of Syntactic Structures. Oxford - New York - Auckland: Oxford University Press. Vol. 2: The Structure of CP and IP: 52-75.

BenincÀ, P., SAlvi, G. \& Frison, L. I988. L’ordine degli elementi della frase e le costruzioni marcate. In L. Renzi, G. Salvi \& A. Cardinaletti (eds.), Grande Grammatica italiana di consultazione. Bologna: Il Mulino. Vol. I: La Frase, i sintagmi nominale e preposizionale: II5-2I5.

Berthier, M.L. 1999. Transcortical Aphasias. Hove: Psychology Press.

Berthier, M.L., Starkstein, S.E., Leiguarda, R., Ruiz, A., Mayberg, H.S., Wagner, H., Price, T.R. \& Robinson, R.G. 199i. Transcortical Aphasia: Importance of the Nonspeech Dominant Hemisphere in Language Repetition. Brain II4 (3): I409-I427.

Bianchi, V. \& Chesi, C. 20Io. Reversing the Perspective on Quantifier Raising. Rivista di Grammatica Generativa 35: 3-38.

Biber, D., Johansson, S., Leech, G., ConRad, S. \& Finegan, E. 1999. Longman Grammar of Spoken and Written English. New York - Harlow: Longman.

BoccI, G. 2004. Aspetti teorici e analisi sperimentale della focalizzazione contrastiva nella periferia sinistra della frase: sintassi, fonologia e fonetica. MA thesis. University of Siena.

Boersma, P. 20or. Praat: A System for Doing Phonetics by Computer. Glot International 5 (9-IO): 34I-345.

Bogousslavsky, J., Regli, F. \& Assal, G. 1988. Acute Transcortical Mixed Aphasia. A Carotid Occlusion Syndrome with Pial and Watershed Infarcts. Brain III (3): 63I-64I.

BošKović, Ž. 200I. On the Nature of the Syntax-Phonology Interface: Cliticization and Related Phenomena. Amsterdam - London - Paris: Elsevier.

BošKović, Ž. \& TAKAHASHI, D. 1998. Scrambling and Last Resort. Linguistic Inquiry 29 (3): $347-366$.

Brunetti, L. 2009. On Links and Tails in Italian. Lingua II9 (5): 756-78I.

Burchert, F., Meissner, N. \& De Bleser, R. 2008. Production of Non-Canonical Sentences in Agrammatic Aphasia: Limits in Representation or Rule Application? Brain and Language IO4 (2): I70-I79.

Cann, R., Kempson, R. \& Marten, L. 2005. The Dynamics of Language. Amsterdam Boston - Heidelberg: Elsevier - Academic Press.

Cardinaletti, A. 2004. Toward a Cartography of Subject Positions. In L. Rizzi (ed.), The Cartography of Syntactic Structures. Oxford - New York - Auckland: Oxford University Press. Vol. 2: The Structure of CP and IP: $115-165$. 
Catani, M. \& Ffytche, D.H. 2005. The Rises and Falls of Disconnection Syndromes. Brain $\mathrm{I} 28$ (IO): 2224-2239.

Chesi, C. 2004. Phases and Cartography in Linguistic Computation: Toward a Cognitively Motivated Computational Model of Linguistic Competence. PhD thesis. University of Siena.

Chomsкy, N. 1995. The Minimalist Program. Cambridge - London: MIT Press.

Chomsкy, N. 200o. Minimalist Inquiries: The Framework. In R. Martin, D. Michaels \& J. Uriagereka (eds.), Step by Step. Essays on Minimalist Syntax in Honor of Howard Lasnik. Cambridge: MIT Press: 89-155.

Cinque, G. 1999. Adverbs and Functional Heads: A Cross-Linguistic Perspective. New York - Oxford: Oxford University Press.

Cinque, G. \& Rizzi, L. 20io. The Cartography of Syntactic Structures. In B. Heine \& H. Narrog (eds.), The Oxford Handbook of Linguistic Analysis. Oxford: Oxford University Press: 5I-65.

Corballis, M.C. 20io. Mirror Neurons and the Evolution of Language. Brain and Language II2 (I): $25-35$.

Couper-Kuhlen, E. \& Thompson, S.A. 2008. On Assessing Situations and Events in Conversation: "Extraposition" and its Relatives. Discourse Studies Io (4): 443-467.

Crosson, B., Moore, A.B., Gopinath, K., White, K.D., Wierenga, C.E., Gaiefsky, M.E., Fabrizio, K.S., Peck, K.K., Soltysik, D., Milsted, C., Briggs, R.W., Conway, T.W. \& Gonzalez Rothi, L.J. 2005. Role of the Right and Left Hemispheres in Recovery of Function during Treatment of Intention in Aphasia. Journal of Cognitive Neuroscience I7 (3): 392-406.

Davis, L., Foldi, N.S., GARDNER, H. \& ZurIF, E.B. 1978. Repetition in the Transcortical Aphasias. Brain and Language 6 (2): 226-238.

Davous, P. \& Boller, F. 1994. Transcortical Alexia with Agraphia Following a Right Temporo-Occipital Hematoma in a Right-Handed Patient. Neuropsychologia 32 (IO): I263-I272.

Di Pellegrino, G., Fadiga, L., Fogassi, L., Gallese, V. \& Rizzolatti, G. 1992. Understanding Motor Events: A Neurophysiological Study. Experimental Brain Research 9I (I): 176-I80.

Dobel, C., Pulvermüller, F., Härle, M., Cohen, R., Kobbel, P., Schönle, P.W. \& Rocкstroh, B. 20oI. Syntactic and Semantic Processing in the Healthy and Aphasic Human Brain. Experimental Brain Research I40 (I): 77-85.

Dragoy, O. \& Bastiannse, R. 2oio. Verb Production and Word Order in Russian Agrammatic Speakers. Aphasiology 24 (I): 28-55.

Evans, N. \& Levinson, S.C. 2009. The Myth of Language Universals: Language Diversity and its Importance for Cognitive Science. Behavioral and Brain Sciences 32 (5): 429-448.

Fanselow, G. 200I. Features, $\theta$-Roles, and Free Constituent Order. Linguistic Inquiry 32 (3): $405-437$.

Fodor, J.A. 1983. The Modularity of Mind: An Essay on Faculty Psychology. Cambridge: MIT Press. 
Frascarelli, M. 1999. The Prosody of Focus in Italian (and the Syntax-Phonology Interface). Probus II (2): 209-238.

Fukui, N. 1993. Parameters and Optionality. Linguistic Inquiry 24 (3): 399-420.

Galantucci, B., Fowler, C.A. \& Turvey, M.T. 2006. The Motor Theory of Speech Perception Reviewed. Psychonomic Bulletin and Review I3 (3): 36I-377.

Gallese, V., Fadiga, L., Fogassi, L. \& Rizzolatti, G. 1996. Action Recognition in the Premotor Cortex. Brain II9 (2): 593-609.

Garraffa, M. 20I. The Grammatical Nature of Minimal Structures: Impoverishment of Grammatical Features in a Non-Fluent Aphasic Speaker. Newcastle upon Tyne: Cambridge Scholars Publishing.

Garraffa, M. \& Grillo, N. 2008. Canonicity Effects as Grammatical Phenomena. Journal of Neurolinguistics 2I (2): I77-197.

Geschwind, N., Quadfasel, F.A. \& Segarra, J.M. 1968. Isolation of the Speech Area. Neuropsychologia 6 (4): 327-340.

Graff-Radford, N.R., Damasio, H., Yamada, T., Eslinger, P.J. \& Damasio, A.R. 1985. Nonhaemorrhagic Thalamic Infarction: Clinical, Neuropsychological and Electrophysiological Findings in Four Anatomical Groups Defined by Computerized Tomography. Brain 108 (2): 485-516.

Grewendorf, G. \& Sabel, J. 1999. Scrambling in German and Japanese: Adjunction vs. Multiple Specifiers. Natural Language and Linguistic Theory I7 (I): I-65.

GrILlo, N. 2009. Generalized Minimality: Feature Impoverishment and Comprehension Deficits in Agrammatism. Lingua II9 (IO): I426-I443.

Haider, H. \& Rosengren, I. 2003. Scrambling: Non-Triggered Chain Formation in OV Languages. Journal of Germanic Linguistics I5 (3): 203-267.

Hale, K.L. 1983. Warlpiri and the Grammar of Non-Configurational Languages. Natural Language and Linguistic Theory I (I): 5-47.

Hale, K.L. 1992. Basic Word Order in Two "Free Word Order" Languages. In D.L. Payne (ed.), Pragmatics of Word Order Flexibility. Amsterdam: J. Benjamins: 63-82.

Hale, K.L., Laughren, M. \& Simpson, J. i995. Warlpiri. In J. Jacobs, A. von Stechow, W. SteRnefeld \& T. Venneman (eds.), Syntax. An International Handbook of Contemporary Research. Berlin - New York: W. de Gruyter: I430-I45I.

Halle, M. \& Marantz, A. 1993. Distributed Morphology and the Pieces of Inflection. In K. Hale \& S.J. Keyser (eds.), The View from Building 20. Cambridge: MIT Press: III-I76.

Heilman, K.M., Tucker, D.M. \& Valenstein, E. i976. A Case of Mixed Transcortical Aphasia with Intact Naming. Brain 99 (3): 415-426.

Ніскок, G. 2009. Eight Problems for the Mirror Neuron Theory of Action Understanding in Monkeys and Humans. Journal of Cognitive Neuroscience 2I (7): 1229-1243.

Holmberg, A. 1986. Word Order and Syntactic Features in the Scandinavian Languages and English. PhD thesis. University of Stockholm.

Hopper, P. \& ThOmpson, S.A. 2008. Projectability and Clause Combining in Interaction. In L. Ritva (ed.), Crosslinguistic Studies of Clause Combining: The Multifunctionality of Conjunctions. Amsterdam: J. Benjamins: 99-I24. 
Karimi, S. 2005. A Minimalist Approach to Scrambling: Evidence from Persian. Berlin: Mouton de Gruyter.

Karimi, S. (ed.) 2003. Word Order and Scrambling. Oxford: Blackwell.

Kastrau, F., Wolter, M., Huber, W. \& Block, F. 2005. Recovery from Aphasia after Hemicraniectomy for Infarction of the Speech-Dominant Hemisphere. Stroke 36 (4): $825-829$.

Kempson, R. \& Kiaer, J. 20Io. Multiple Long-Distance Scrambling: Syntax as Reflections of Processing. Journal of Linguistics 46 (I): 127-192.

Kempson, R., Meyer-Viol, W. \& Gabbay, D.M. 20oi. Dynamic Syntax: The Flow of Language Understanding. Oxford: Blackwell.

Kiaer, J. \& Kempson, R. 2005. Pro-active Parsing of Korean Scrambling. In J. Alderete, C.-H. Han \& A. Kochetov (eds.), Proceedings of the 24th West Coast Conference on Formal Linguistics: WCCFL 24. Somerville: Cascadilla Press: 209-217.

KIss, K.É. I998. Identificational Focus versus Information Focus. Language 74 (2): 245-273.

Kohler, E., Keysers, C., Umiltà, M.A., Fogassi, L., Gallese, V. \& Rizzolatti, G. 2002. Hearing Sounds, Understanding Actions: Action Representation in Mirror Neurons. Science 297 (5582): 846-848.

Kural, M. 1992. Properties of Scrambling in Turkish. Unpublished manuscript. UCLA.

LADD, D.R. 2008. Intonational Phonology. Cambridge: Cambridge University Press.

Lieberman, P. 2007. The Evolution of Human Speech. Current Anthropology 48 (I): 39-46.

Lотто, A.J., Ніскок, G.S. \& Holt, L.L. 2009. Reflections on Mirror Neurons and Speech Perception. Trends in Cognitive Sciences I3 (3): IIO-II4.

Luzzatti, C., Willmes, K. \& De Bleser, R. 1996. Aachener Aphasie Test. Versione italiana. Florence: Organizzazioni Speciali [2nd edition].

Maeshima, S., Nakagawa, M., Terada, T., Nakai, K., Itakura, T., Komai, N. \& Roger, P. 1999. Transcortical Mixed Aphasia from Ischaemic Infarcts in a Non-Right Handed Patient. Journal of Neurology 246 (6): 504-506.

Mahajan, A. 1990. The A/A-bar Distinction and Movement Theory. PhD thesis. MIT. Cambridge (Mass.).

Mahajan, A. 1994. Toward a Unified Theory of Scrambling. In N. Corver \& H. VAN RiEMSDijK (eds.), Studies on Scrambling: Movement and Non-Movement Approaches to Free Word-Order Phenomena. Berlin: Mouton de Gruyter: 30I-333.

McFarling, D., Rothi, L.J. \& Heilman, K.M. I982. Transcortical Aphasia from Ischaemic Infarcts of the Thalamus: A Report of Two Cases. Journal of Neurology, Neurosurgery and Psychiatry 45 (2): I07-II2.

Miceli, G., Laudanna, A., Burani, C. \& Capasso, R. 1994. Batteria per l'Analisi dei Deficit Afasici - BADA. Roma: CEPSAG, Università Cattolica del Sacro Cuore.

Miунмото, E.T. 2002. Case Markers as Clause Boundary Inducers in Japanese. Journal of Psycholinguistic Research 3I (4): 307-347.

Mohr, B., Pulvermüller, F. \& ZAidel, E. 1994. Lexical Decision after Left, Right and Bilateral Presentation of Function Words, Content Words and Non-Words: Evidence for Interhemispheric Interaction. Neuropsychologia 32 (I): I05-I24. 
Moro, A., Tettamanti, M., Perani, D., Donati, C., Cappa, S.F. \& Fazio, F. 200 . Syntax and the Brain: Disentangling Grammar by Selective Anomalies. Neuroimage I3 (I): IIO-II8.

Müller, G. \& Sternefeld, W. 1993. Improper Movement and Unambiguous Binding. Linguistic Inquiry 24 (3): 46I-507.

Musso, M., Moro, A., Glauche, V., Rujntjes, M., Reichenbach, J., Buchel, C. \& Weiller, C. 2003. Broca's Area and the Language Instinct. Nature Neuroscience 6 (7): 774-78I.

Nagaratnam, N. \& Gilhotra, J.S. 1998. Acute Mixed Transcortical Aphasia Following an Infarction in the Left Putamen. Aphasiology I2 (6): 489-493.

Nagaratnam, N. \& Nagaratnam, K. 2000. Acute Mixed Transcortical Aphasia with Bihemispheric Neurological Deficits Following Diffuse Cerebral Dysfunction. Aphasiology I4 (9): 893-899.

Neeleman, A. 1994. Scrambling as a D-structure Phenomenon. In N. Corver \& H. VAN RiemsDijK (eds.), Studies on Scrambling: Movement and Non-Movement Approaches to Free Word-Order Phenomena. Berlin: Mouton de Gruyter: 387-429.

Obenauer, H.-G. 1976. Études de syntaxe interrogative du français: quoi, combien et le complémenteur. Tübingen: M. Niemeyer.

OrdóñEz, F. 1998. The Inversion Construction in Interrogatives in Spanish and Catalan. In J. Lema \& E. Treviño (eds.), Theoretical Analyses on Romance Languages. Amsterdam: J. Benjamins: 329-350.

Orsini, A., Grossi, D., Capitani, E., Laiacona, M., Papagno, C. \& Valler, G. i987. Verbal and Spatial Immediate Memory Span: Normative Data from 1355 Adults and III2 Children. Italian Journal of Neurological Sciences 8 (6): 539-548.

Pedersen, P.M., Vinter, K. \& Olsen, T.S. 2004. Aphasia after Stroke: Type, Severity and Prognosis. The Copenhagen Aphasia Study. Cerebrovascular Diseases I7 (I): 35-43.

Pensalfini, R. 2004. Towards a Typology of Configurationality. Natural Language and Linguistic Theory 22 (2): 359-408.

Phillips, C. 2003. Linear Order and Constituency. Linguistic Inquiry 34 (I): 37-90.

Pulvermüller, F. \& Berthier, M.L. 2008. Aphasia Therapy on a Neuroscience Basis. Aphasiology 22 (6): 563-599.

Pulvermüller, F. \& Schönle, P.-W. 1993. Behavioral and Neuronal Changes during Treatment of Mixed Transcortical Aphasia: A Case Study. Cognition 48 (2): I39-I6I.

Rapcsak, S.Z., Krupp, L.B., Rubens, A.B. \& Reim, J. I990. Mixed Transcortical Aphasia without Anatomic Isolation of the Speech Area. Stroke 2I (6): 953-956.

Richards, N. 200I. Movement in Language: Interactions and Architectures. Oxford: Oxford University Press.

Rizzi, L. I997. The Fine Structure of the Left Periphery. In L. HaEgeman (ed.), Elements of Grammar: Handbook in Generative Syntax. Dordrecht - London: Kluwer Academic Publishers: $28 \mathrm{I}-337$.

RizzI, L. 200I. On the Position "Int(errogative)" in the Left Periphery of the Clause. In G. Cinque \& G. Salvi (eds.), Current Studies in Italian Syntax. Amsterdam - London: Elsevier: $287-296$. 
RizzI, L. 2006. On the Form of Chains: Criterial Positions and ECP Effects. In L. CHENG \& N. Corver (eds.), Wh-Movement: Moving on. Cambridge: MIT Press: 97-I33.

Rizzi, L. \& Shlonsky, U. 2007. Strategies of Subject Extraction. In H.-M. Gärtner \& U. SAuerland (eds.), Interfaces + Recursion = Language? Berlin: Mouton de Gruyter: II5-I6o.

Rizzolatti, G. \& Arbib, M.A. 1998. Language within Our Grasp. Trends in Neurosciences 2I (5): I88-I94.

Rizzolatti, G. \& Craighero, L. 2004. The Mirror-Neuron System. Annual Review of Neuroscience 27: 169-192.

Ross, J.R. 1967. Constraints on Variables in Syntax. PhD thesis. MIT. Cambridge (Mass.).

Rubens, A.B. 1976. Transcortical Motor Aphasia. In H. Whitaker \& H.A. Whitaker (eds.), Studies in neurolinguistics. New York - London: Academic Press: 293-306.

Sabel, J. \& Saito, M. 2005. The Free Word Order Phenomenon: Its Syntactic Sources and Diversity. Berlin: Mouton de Gruyter.

SAIto, M. 1985. Some Asymmetries in Japanese and Their Theoretical Implications. $\mathrm{PhD}$ thesis. MIT. Cambridge (Mass.).

SAIto, M. 1992. Long-Distance Scrambling in Japanese. Journal of East Asian Linguistics I (I): 69-II8.

SAmeK-Lodovici, V. 2009. Topic, Focus, and Background in Italian Clauses. In A. Dufter \& D. JАСов (eds.), Focus and Background in Romance Languages. Amsterdam: J. Benjamins: 333-357.

Schoenberg, M.R. \& Scott, J.G. 2oir. Aphasia Syndromes. In M.R. Schoenberg \& J.G. Scott (eds.), The Little Black Book of Neuropsychology: A Syndrome-Based Approach. Boston: Springer: 267-292.

Shapiro, L.P., Gordon, B., Hack, N. \& Killackey, J. I993. Verb-Argument Structure Processing in Complex Sentences in Broca's and Wernicke's Aphasia. Brain and Language $45(3): 423-447$.

Shapiro, L.P., Zurif, E.B. \& Grimshaw, J. 1987. Sentence Processing and the Mental Representation of Verbs. Cognition 27 (3): 219-246.

Speedie, L.J., Coslett, B. \& Heilman, K.M. 1984. Repetition of Affective Prosody in Mixed Transcortical Aphasia. Archives of Neurology 4I (3): 268-270.

Thompson, C.K. 2003. Unaccusative Verb Production in Agrammatic Aphasia: The Argument Structure Complexity Hypothesis. Journal of Neurolinguistics I6 (2-3): I $5 \mathrm{I}-\mathrm{I} 67$.

Thompson, C.K., Lange, K.L., Schneider, S.L. \& Shapiro, L.P. I997. Agrammatic and Non-Brain-Damaged Subjects' Verb and Verb Argument Structure Production. Aphasiology II (4-5): 473-490.

Torrego, E. 1984. On Inversion in Spanish and Some of Its Effects. Linguistic Inquiry I5 (I): IO3-I29.

Trueswell, J.C., Tanenhaus, M.K. \& Kello, C. I993. Verb-Specific Constraints in Sentence Processing: Separating Effects of Lexical Preference from Garden-Paths. Journal of Experimental Psychology: Learning, Memory, and Cognition 19 (3): 528-553. 
Venezia, J.H. \& Нiскок, G. 2009. Mirror Neurons, the Motor System and Language: From the Motor Theory to Embodied Cognition and Beyond. Language and Linguistics Compass 3 (6): I403-I4I6.

Webelhuth, G. 1990. Diagnostics for Structure. In G. Grewendorf \& W. Sternefeld (eds.), Scrambling and Barriers. Amsterdam: J. Benjamins: 4I-75.

Yankovsky, A.E. \& Treves, T.A. 2002. Postictal Mixed Transcortical Aphasia. Seizure II (4): 278-279.

Yarbay Duman, T., Aygen, G., Ozgirgin, N. \& Bastiaanse, R. 2007. Object Scrambling and Finiteness in Turkish Agrammatic Production. Journal of Neurolinguistics 20 (4): 306-33I.

\section{Appendix A. Preliminary task}

\section{Ungrammatical sentences}

\begin{tabular}{|l|l|}
\hline Il nonno gioca da carte tutte le sere. & Il nonno gioca la carte tutte le sere. \\
\hline Gli sposi stampano gli inviti carta bianca. & + \\
\hline $\begin{array}{l}\text { Il nonno compra una pianta nuova per } \\
\text { giardino. }\end{array}$ & Il nonno compra pianta nuova per giardino. \\
\hline I bambini attaccano i disegni con colla. & Con colla i bambini attaccano i disegni. \\
\hline Gli attori provano lontano gli sguardi. & + \\
\hline La penna cade fuori dallo astuccio. & La penna cade fuori dall'astuccio. \\
\hline Compro lo zaino nuovo bambina. & Bambina compro lo zaino nuovo. \\
\hline Dopo lo sbarco agli aereo sono tranquilla. & Sono tranquilla dopo gli sbarchi agli aerei. \\
\hline Lo zio dorme davanti nella televisione. & Lo zio dorme davanti della televisione. \\
\hline Mario cammina gli scogli e guarda l'alba. & + \\
\hline Marco fa le visite guidate i turisti. & Dai turisti. \\
\hline Il cane è scappato il cancello principale. & NO \\
\hline Accendo il fuoco lontano le piante. & Lontano le piante accendo il fuoco. \\
\hline La mamma aspetta Maria fuori scuola. & Maria aspetta la mamma fuori scuola. \\
\hline I turisti aspettano fuori sui musei. & Sui musei aspettano fuori i turisti. \\
\hline I miei amici lavorano lontano Roma. & Lontano Roma lavorano i miei amici. \\
\hline $\begin{array}{l}\text { Le alunne ricevono un premio per le } \\
\text { impegno. }\end{array}$ & Per l'impegno. \\
\hline Le mie amiche sono tornate la spiaggia. & Le amiche mie sono tornate dalla spiaggia. \\
\hline L’attore si esibisce davanti pubblico. & Davanti al pubblico l'attore si esibisce. \\
\hline
\end{tabular}




\begin{tabular}{|c|c|}
\hline I bambini ci salutano da finestre. & Dalle finestre i bambini ci salutano. \\
\hline I bambini giocano vicino dello fiume. & I vicini giocano. \\
\hline L'atleta si mantiene in forma con la sport. & Lo sport si mantiene in forma con l'atleta. \\
\hline Il bandito è scappato fuori lo stato. & Dallo stadio è scappato fuori il bandito. \\
\hline Marco è caduto davanti alla miei occhi. & NO \\
\hline Durante le prove ballerò tra Maria. & Tra Maria ballerò durante le prove. \\
\hline Lo studente prepara la musica con la festa. & + \\
\hline L'alpinista cammina lontano il burrone. & L'alpinista cammina lontano dal burrone. \\
\hline Gli impiegati lavorano davanti alle schermi. & Davanti agli schermi lavorano gli impiegati. \\
\hline I ragazzi si baciano davanti Marco. & Davanti Marco i ragazzi si baciano. \\
\hline Mario esce tutti i sabati amici. & + \\
\hline I ragazzi giocano sullo spiaggia tutta l'estate. & I ragazzi giocano sulla spiaggia tutta l'estate. \\
\hline Ho perso la collana bianca mamma. & Mamma ho perso la collana. \\
\hline Maria ha visto la pinna di squalo. & La pinna di squalo è stata vista da Maria. \\
\hline $\begin{array}{l}\text { Gli uomini mettono la giacca con bottoni } \\
\text { blu. }\end{array}$ & + \\
\hline L'artista usa le foglie di alberi. & NO \\
\hline Gli storici sanno la storia tra le Maya. & Tra le maya gli storici sanno la storia. \\
\hline L'altro ieri avevo un gran mal testa. & Mal di testa. \\
\hline Lascio la biancheria fuori dai armadi. & Lascio la biancheria fuori dagli armadi. \\
\hline La palla è finita vicino dallo scivolo. & La palla è finita vicino allo scivolo. \\
\hline Il bambino è salito alle sgabello. & Bambina salita alle sgabello. \\
\hline I negozi vietano l'ingresso con la animali. & Con la animali. \\
\hline Le modelle litigano il fotografo. & + \\
\hline Il satellite sta vagando per spazio. & Il satellite sta vagando per lo spazio. \\
\hline Gianni ha una grande passione nella animali. & Gianni ba la passione per gli animali. \\
\hline Ho messo lo straccio vicino nei detersivi. & Dove ho messo lo straccio? Vicino ai detersivi. \\
\hline I film violenti sono vietati agli minori. & Ai minori sono vietati i film violenti. \\
\hline Il treno passa lontano dal città. & Dalla città il treno passa lontano. \\
\hline La nonna porta i bambini a parco. & Al parco portano i bambini dalla nonna. \\
\hline Le strade sono ripulite sullo spazzino. & Dallo spazzino sono ripulite le strade. \\
\hline
\end{tabular}




\begin{tabular}{|l|l|}
\hline Gli ospiti vengono serviti sul camerieri. & Sui camerieri vengono serviti gli ospiti. \\
\hline Lo spettacolo inizia a 20. & Lo spettacolo si inizia a zo. \\
\hline Gli alunni hanno paura sul maestro. & Sul maestro gli alunni hanno paura. \\
\hline Le tue scarpe sono vicino nella stivali. & Nelle stivali sono le tue scarpe. \\
\hline Marta è innamorata l'amico di Luigi. & L'amico di Luigi è innamorato di Marta. \\
\hline Il signore mette lo scatolone su armadio. & Sull'armadio mette lo scatolone il signore. \\
\hline Maria si arrende davanti sui difficoltà. & NO \\
\hline Marco ha una voce fuori nel comune. & Dal comune. \\
\hline Le bambine si trovano davanti dell'entrata. & Davanti all'entrata si trovano le bambine. \\
\hline Lo studente abita lontano università. & Lontano dall'università abita lo studente. \\
\hline
\end{tabular}

\section{Appendix B. Items of the experimental task}

\section{Sentences without adjuncts or optional complements}

\begin{tabular}{|l|l|}
\hline La macedonia si mangia con il cucchiaino. & + \\
\hline Lo specchio riflette la mia immagine. & + \\
\hline La porta è stata chiusa dal vento. & + \\
\hline Il cavallo galoppa veloce. & + \\
\hline La paura mangia l'anima. & + \\
\hline Gianni si è fatto giustizia da solo. & + \\
\hline I pinguini vivono in Antartide. & + \\
\hline La Libia è stata liberata dagli insorti. & Gli insorti hanno liberato la Libia. \\
\hline La medicina non è una scienza esatta. & Medicina non è una scienza esatta. \\
\hline Le banane contengono potassio. & + \\
\hline I cuccioli giocano felici. & + \\
\hline Leggere il giornale è istruttivo. & + \\
\hline Le industrie inquinano l'ambiente. & + \\
\hline Il gatto gioca col gomitolo. & + \\
\hline A carnevale si mangiano le frittelle. & + \\
\hline I troppi caffè ci rendono nervosi. & + \\
\hline Gianni teme molto i fulmini. & + \\
\hline
\end{tabular}




\begin{tabular}{|c|c|}
\hline Ti sposerò se mi sarai fedele. & + \\
\hline $\begin{array}{l}\text { Mangiare velocemente è una cattiva } \\
\text { abitudine. }\end{array}$ & + \\
\hline Anche se piangi non ti prenderò in braccio. & + \\
\hline Verrò a Parigi quando sarà primavera. & + \\
\hline $\begin{array}{l}\text { Le campane iniziano a suonare alle } 7 \mathrm{di} \\
\text { mattina. }\end{array}$ & + \\
\hline La foto sul muro fu la causa della rivolta. & + \\
\hline $\begin{array}{l}\text { Quell'ignorante del medico mi ha prescritto } \\
\text { troppi antibiotici. }\end{array}$ & $\begin{array}{l}\text { Ignorante del medico mi ba prescritto troppi } \\
\text { antibiotici. }\end{array}$ \\
\hline E' arrivato il momento di andare via di casa. & + \\
\hline Telefono a Maria per invitarla alla festa. & + \\
\hline E' uscito un film interessante. & + \\
\hline L'autobus giallo è pieno di turisti stranieri. & + \\
\hline Marco vive nella casa bianca. & + \\
\hline Bisogna sempre tenersi informati. & + \\
\hline Sono molto contenta del mio nuovo lavoro. & + \\
\hline Hanno individuato un nuovo pianeta. & + \\
\hline Gianni ha perso l'orologio nuovo. & + \\
\hline Hanno scoperto una nuova specie animale. & + \\
\hline La giacca nera è nell'armadio. & + \\
\hline $\begin{array}{l}\text { Il giorno di Natale pranzo con i miei } \\
\text { genitori. }\end{array}$ & + \\
\hline Ho passato il capodanno da Marco. & + \\
\hline Gianni porta sempre suo figlio allo stadio. & + \\
\hline La protesta è organizzata dagli studenti. & + \\
\hline Marco deve stare lontano dai guai. & + \\
\hline Il bagno pubblico è vicino all'uscita. & + \\
\hline Simone sta mangiando una mela. & + \\
\hline $\begin{array}{l}\text { Gianni ha assaggiato la torta che Francesca } \\
\text { ha preparato. }\end{array}$ & + \\
\hline Filippo guarda la televisione. & + \\
\hline $\begin{array}{l}\text { Maria prepara il pranzo mentre Gianni } \\
\text { guarda la tv. }\end{array}$ & + \\
\hline
\end{tabular}




\begin{tabular}{|c|c|}
\hline Maria è andata al mare. & + \\
\hline Il buio era cosi fitto da non distinguere nulla. & + \\
\hline Quell'uomo sembra mio zio. & + \\
\hline Giacomo Leopardi era un poeta. & + \\
\hline $\begin{array}{l}\text { Mi è stato consigliato di non prendere questa } \\
\text { strada. }\end{array}$ & + \\
\hline Mio fratello ha le idee chiare. & + \\
\hline $\begin{array}{l}\text { E' difficile decidere quale film andare a } \\
\text { vedere. }\end{array}$ & + \\
\hline Andrea ha pescato una trota. & + \\
\hline $\begin{array}{l}\text { I guardiani li hanno appena notati prima che } \\
\text { fuggissero. }\end{array}$ & NO \\
\hline $\begin{array}{l}\text { So che siete stanchi ma dobbiamo } \\
\text { proseguire. }\end{array}$ & + \\
\hline $\begin{array}{l}\text { I geologi sono riusciti a capire quanti anni } \\
\text { hanno queste rocce. }\end{array}$ & + \\
\hline Nicola impazzisce per il gelato. & + \\
\hline $\begin{array}{l}\text { La lebbra è una malattia che esiste ancora nel } \\
\text { mondo. }\end{array}$ & La lebbra è una malattia che esiste nel mondo. \\
\hline Ho comprato la carne di maiale. & + \\
\hline $\begin{array}{l}\text { È quasi impossibile che i democratici } \\
\text { permettano una cosa del genere. }\end{array}$ & + \\
\hline La città nella quale sono nato è splendida. & + \\
\hline $\begin{array}{l}\text { Il libro sul tavolo mi è stato regalato da } \\
\text { Giovanna. }\end{array}$ & $\mathrm{NO}$ \\
\hline Il governo non vuole le elezioni. & + \\
\hline Oggi pranzerò insieme a Giovanni. & + \\
\hline Ho bevuto una birra perché avevo sete. & + \\
\hline Quando arriverete verrò a prendervi. & + \\
\hline La lezione di matematica era noiosa. & + \\
\hline Sarebbe un peccato non arrivare in tempo. & + \\
\hline Lucia adora i pistacchi. & + \\
\hline $\begin{array}{l}\text { Sono contenta che tu abbia accettato il mio } \\
\text { invito. }\end{array}$ & Sono contenta che abbia accettato il mio invito. \\
\hline La maratona è stata vinta da un etiope. & + \\
\hline
\end{tabular}




\begin{tabular}{|c|c|}
\hline Guglielmo Tell era bravo a colpire le mele. & + \\
\hline Siena è la città del palio. & + \\
\hline Pensai che fosse meglio dirle la verità. & Fosse meglio. \\
\hline Il gatto ha inseguito il topo. & + \\
\hline Ci dispiaceva che Luigi non fosse con noi. & + \\
\hline Mi piacciono i libri di storia. & + \\
\hline Ieri ho incontrato il dentista di Maria. & + \\
\hline Si è fulminata la lampadina del salotto. & + \\
\hline L'orologio del soldato segna le due. & + \\
\hline Festeggiamo la promozione di Maria. & + \\
\hline Le tradizioni della mia città sono importanti. & + \\
\hline La barca del pescatore arriva al porto. & + \\
\hline Marco guida la macchina di Gianni. & + \\
\hline Sono arrivati gli amici di Maria. & + \\
\hline Il comico ha inventato una battuta di spirito. & + \\
\hline Mangio una frittella alla crema. & + \\
\hline Marco prende lo sciroppo per la tosse. & + \\
\hline La donna indossa un cappotto di lana. & + \\
\hline Ho letto l'opera sui cavalieri medievali. & L'opera sui cavalieri medievali l'bo letta. \\
\hline I vichinghi sono stati grandi navigatori. & + \\
\hline Le lontre sono animali acquatici. & + \\
\hline Questo tramonto sembra un miracolo. & + \\
\hline Le scale della casa sono ripide. & + \\
\hline L'Everest è la cima più alta del mondo. & + \\
\hline Le lezioni del prof. Ferri erano soporifere. & + \\
\hline $\begin{array}{l}\text { Gli occhi di Maria sono di un azzurro } \\
\text { intenso. }\end{array}$ & + \\
\hline $\begin{array}{l}\text { I fenici avevano la flotta più grande del } \\
\text { mediterraneo. }\end{array}$ & + \\
\hline Marcello ha tre bimbi bellissimi. & + \\
\hline I leoni hanno fame. & + \\
\hline $\begin{array}{l}\text { I colibrì sono gli uccelli più piccoli del } \\
\text { mondo. }\end{array}$ & + \\
\hline
\end{tabular}




\begin{tabular}{|l|l|}
\hline Gianni ha molti dischi dei Beatles. & + \\
\hline Simone ha vissuto una vita intensa. & + \\
\hline Il rinoceronte è un animale africano. & + \\
\hline Questo sapone sa di menta. & + \\
\hline Luca si è comportato bene. & + \\
\hline San Francesco è il patrono d'Italia. & + \\
\hline La battaglia è finita. & + \\
\hline Queste foglie sono ricche di clorofilla. & + \\
\hline I tulipani sono il simbolo dell'Olanda. & + \\
\hline La causa della rivolta fu la foto sul muro. & + \\
\hline La struttura dell'atomo è stata esplorata. & + \\
\hline Il materasso è stato rubato. & + \\
\hline $\begin{array}{l}\text { La distruzione del nemico spense ogni } \\
\text { resistenza. }\end{array}$ & + \\
\hline I film di guerra sono brutti. & + \\
\hline Ho sempre del denaro. & + \\
\hline I miei sentimenti sono stati feriti. & + \\
\hline Maurizio risponde a Michele. & + \\
\hline Questi gatti sono matti. & + \\
\hline Firenze è una città turistica. & + \\
\hline
\end{tabular}

\section{Sentences which contain adjuncts or optional complements}

\begin{tabular}{|l|l|}
\hline $\begin{array}{l}\text { I. I bambini aspettano l'estate con } \\
\text { impazienza. }\end{array}$ & + \\
\hline $\begin{array}{l}\text { 2. Mi sono svegliato molto presto questa } \\
\text { mattina. }\end{array}$ & Questa mattina mi sono svegliato molto presto. \\
\hline 3. Ho cucinato il pollo in umido. & + \\
\hline 4. L'aquilone vola alto nel cielo. & + \\
\hline 5. Il ventilatore è acceso in salotto. & + \\
\hline 6. La finestra sbatte per il vento. & + \\
\hline 7. La nave getta l'ancora in mare. & + \\
\hline $\begin{array}{l}\text { 8. Mario ha pescato un luccio enorme nel } \\
\text { lago. }\end{array}$ & Nel lago Mario ha pescato un luccio grande. \\
\hline
\end{tabular}




\begin{tabular}{|c|c|}
\hline 9. Mio zio a preso il mal di gola di nuovo. & + \\
\hline Io. La verdura fa bene alla salute. & + \\
\hline II. Il vigile controlla il traffico accuratamente. & + \\
\hline I2. Ho sfogliato il libro con interesse. & Con interesse bo sfogliato il libro. \\
\hline I3. Ripongo le posate nel cassetto. & + \\
\hline I4. Il sole spunta tra le nuvole. & + \\
\hline I5. Il camino sta acceso tutto il giorno. & + \\
\hline I6. Il bicchiere è caduto dalla tavola. & + \\
\hline 17. Mio marito mi aspetta davanti al negozio. & + \\
\hline I8. Gianni va in bicicletta senza mani. & + \\
\hline $\begin{array}{l}\text { 19. Luisa ha dedicato tutto il suo tempo a } \\
\text { Michele la scorsa settimana. }\end{array}$ & $\begin{array}{l}\text { La scorsa settimana Luisa ba dedicato il suo } \\
\text { tempo a Michele. }\end{array}$ \\
\hline $\begin{array}{l}\text { 20. Giovanni ha caricato stamattina il } \\
\text { camion di scatole. }\end{array}$ & + \\
\hline $\begin{array}{l}\text { 2I. Il cantante ha offerto uno spettacolo } \\
\text { bellissimo al pubblico l'altra notte. }\end{array}$ & $\begin{array}{l}\text { Il cantante ba offerto uno spettacolo bellissimo } \\
\text { al pubblico. }\end{array}$ \\
\hline $\begin{array}{l}\text { 22. Il maestro ha dato un brutto voto nel } \\
\text { compito in classe a Luigi. }\end{array}$ & NO \\
\hline $\begin{array}{l}\text { 23. Ho trascorso le vacanze in Sardegna per } \\
\text { molti anni. }\end{array}$ & $\begin{array}{l}\text { Ho trascorso in Sardegna le vacanze per molti } \\
\text { anni. }\end{array}$ \\
\hline $\begin{array}{l}\text { 24. Il cameriere ha servito con un'ora di } \\
\text { ritardo la pizza ai clienti. }\end{array}$ & $\begin{array}{l}\text { Il cameriere ba servito la pizza ai clienti con un } \\
\text { quarto d'ora di ritardo. }\end{array}$ \\
\hline $\begin{array}{l}\text { 25. Quel ragazzo ha imbrattato il muro di } \\
\text { scritte oscene stanotte. }\end{array}$ & Stanotte. \\
\hline $\begin{array}{l}\text { 26. Ho prestato il mio libro a un collega } \\
\text { Lunedì scorso. }\end{array}$ & Ho prestato un libro a un collega lunedì scorso. \\
\hline $\begin{array}{l}\text { 27. La compagnia telefonica spedirà una } \\
\text { lettera il mese prossimo ai clienti francesi. }\end{array}$ & $\begin{array}{l}\text { Ai clienti francesi la compagnia spedirà una } \\
\text { lettera il mese prossimo. }\end{array}$ \\
\hline $\begin{array}{l}\text { 28. La mamma ha mandato i bambini dalla } \\
\text { nonna due domeniche fa. }\end{array}$ & + \\
\hline $\begin{array}{l}\text { 29. Matteo presta con troppa facilità tutto } \\
\text { a tutti. }\end{array}$ & + \\
\hline $\begin{array}{l}\text { 30. Ho dato al giudice la mia parola d'onore } \\
\text { durante il processo. }\end{array}$ & $\begin{array}{l}\text { Ho dato al giudice la parola d'onore durante il } \\
\text { processo. }\end{array}$ \\
\hline $\begin{array}{l}\text { 3I. Il reattore nucleare dà molte } \\
\text { preoccupazioni in queste ore ai giapponesi. }\end{array}$ & $\begin{array}{l}\text { Ai giapponesi il reattore nucleare dà molte } \\
\text { preoccupazioni. }\end{array}$ \\
\hline
\end{tabular}




\begin{tabular}{|c|c|}
\hline $\begin{array}{l}\text { 32. Ho inviato un biglietto d'auguri a Marco } \\
\text { per Natale. }\end{array}$ & + \\
\hline $\begin{array}{l}\text { 33. Marco chiede tutti i giorni un favore a } \\
\text { Gianni. }\end{array}$ & + \\
\hline $\begin{array}{l}\text { 34. La nonna ha donato una caramella al suo } \\
\text { nipotino preferito. }\end{array}$ & + \\
\hline $\begin{array}{l}\text { 35. Porterò una bottiglia di vino a Marco } \\
\text { questa sera. }\end{array}$ & + \\
\hline $\begin{array}{l}\text { 36. La guida indica la strada con l'ombrello } \\
\text { ai turisti. }\end{array}$ & + \\
\hline $\begin{array}{l}\text { 37. I volontari distribuiscono ogni sabato gli } \\
\text { aiuti ai poveri. }\end{array}$ & + \\
\hline $\begin{array}{l}\text { 38. Ho ricevuto una lettera Ieri dal mio } \\
\text { amico inglese. }\end{array}$ & + \\
\hline $\begin{array}{l}\text { 39. Giovanni ha mangiato la torta con } \\
\text { voracità. }\end{array}$ & + \\
\hline 40. Vorrei andare in vacanza al più presto. & + \\
\hline $\begin{array}{l}\text { 4I. Gianni ha telefonato a Maria con il suo } \\
\text { cellulare. }\end{array}$ & + \\
\hline 42. I ragazzi bevono birra al pub. & + \\
\hline $\begin{array}{l}\text { 43. I ragazzi guardano la tv satellitare di } \\
\text { pomeriggio. }\end{array}$ & $\begin{array}{l}\text { I ragazzi di pomeriggio guardano la tv } \\
\text { satellitare. }\end{array}$ \\
\hline $\begin{array}{l}\text { 44. Ho pranzato con Lucia al ristorante sul } \\
\text { lago. }\end{array}$ & + \\
\hline $\begin{array}{l}\text { 45. Andrea ha conosciuto Maria a Parigi un } \\
\text { anno fa. }\end{array}$ & + \\
\hline $\begin{array}{l}\text { 46. Abbiamo parlato di politica tutta la sera } \\
\text { con Sandro. }\end{array}$ & $\begin{array}{l}\text { Con Sandro abbiamo parlato di politica tutta } \\
\text { la sera. }\end{array}$ \\
\hline 47. Oggi ricorre il nostro anniversario. & + \\
\hline $\begin{array}{l}\text { 48. Anche questa volta la macchina non } \\
\text { parte. }\end{array}$ & + \\
\hline $\begin{array}{l}\text { 49. La modella indossa un abito elegante per } \\
\text { la sfilata. }\end{array}$ & + \\
\hline $\begin{array}{l}\text { 50. La Caritas conta su tanti volontari locali } \\
\text { in India. }\end{array}$ & + \\
\hline $\begin{array}{l}\text { 5I. Ho studiato molti libri per preparare } \\
\text { l'esame d'inglese. }\end{array}$ & + \\
\hline
\end{tabular}




\begin{tabular}{|c|c|}
\hline $\begin{array}{l}\text { 52. Gianni sta camminando a piedi scalzi in } \\
\text { giardino. }\end{array}$ & + \\
\hline $\begin{array}{l}\text { 53. Luca ha visto una stella cadente a occhio } \\
\text { nudo. }\end{array}$ & + \\
\hline $\begin{array}{l}\text { 54. Lucia sta bollendo le patate in acqua } \\
\text { salata. }\end{array}$ & + \\
\hline $\begin{array}{l}55 . \text { I marziani sono atterrati con la navicella } \\
\text { spaziale. }\end{array}$ & + \\
\hline 56. L'autista guida il camion in autostrada. & Guida il camion in autostrada. \\
\hline 57. Gianni lava la macchina dietro casa sua. & + \\
\hline $\begin{array}{l}\text { 58. Il cane sotterra l'osso nel prato con } \\
\text { astuzia. }\end{array}$ & Sotterra l'osso con il prato con astuzia. \\
\hline 59. Luca si è tagliato con la carta. & + \\
\hline 6o. Ho trovato una moneta sotto il letto. & Sotto il letto bo trovato una moneta. \\
\hline $\begin{array}{l}\text { 6I. Ho giocato a domino con un mio vecchio } \\
\text { amico. }\end{array}$ & Mio vecchio amico. \\
\hline $\begin{array}{l}\text { 62. L'uomo canta un canzone triste con il } \\
\text { microfono. }\end{array}$ & $\begin{array}{l}\text { L'uomo canta con il microfono una canzone } \\
\text { triste. }\end{array}$ \\
\hline $\begin{array}{l}\text { 63. La signora compra l'insalata verde al } \\
\text { mercato. }\end{array}$ & + \\
\hline $\begin{array}{l}\text { 64. Hanno annunciato la morte del re alla } \\
\text { televisione. }\end{array}$ & $\begin{array}{l}\text { Alla televisione banno annunciato la morte del } \\
\text { re. }\end{array}$ \\
\hline $\begin{array}{l}\text { 65. Maria appoggia il quaderno grande sul } \\
\text { tavolo. }\end{array}$ & + \\
\hline 66. Andiamo al mare ogni anno in Sardegna. & Ogni anno andiamo al mare in Sardegna. \\
\hline 67. Il cane riporta l'osso al padrone. & + \\
\hline $\begin{array}{l}\text { 68. L'uccello vola sul tetto rosso della casa } \\
\text { più alta. }\end{array}$ & $\begin{array}{l}\text { L'uccello vola sul tetto più rosso della casa più } \\
\text { alta. }\end{array}$ \\
\hline 69. Gianni mangia un panino in fretta. & + \\
\hline 70. Ascolto la radio mentre guido. & + \\
\hline 7I. Il ragazzo alto parla al telefono. & + \\
\hline $\begin{array}{l}\text { 72. Maria compra un vestito rosso per la } \\
\text { festa. }\end{array}$ & Maria per la festa compra un vestito rosso. \\
\hline 73. Il bambino biondo corre sul prato. & + \\
\hline $\begin{array}{l}\text { 74. Maria ha fatto una coperta di lana in due } \\
\text { giorni. }\end{array}$ & + \\
\hline
\end{tabular}




\begin{tabular}{|c|c|}
\hline 75. Carlo guarda un film noioso al cinema. & + \\
\hline $\begin{array}{l}\text { 76. Aspettiamo i risultati degli esami con } \\
\text { ansia. }\end{array}$ & + \\
\hline 77. Il papà prende il treno tutti i giorni. & + \\
\hline 78. Il gatto salta sul divano blu. & + \\
\hline 79. Leggo il giornale tutte le mattine. & + \\
\hline 80. Maria nuota nell'acqua alta. & + \\
\hline 81. Gli amici giocano a calcio insieme. & + \\
\hline 82. La maestra corregge con la penna rossa. & + \\
\hline 83. L’uomo legge il giornale con gli occhiali. & + \\
\hline 84. Il treno arriva in stazione lentamente. & + \\
\hline $\begin{array}{l}\text { 85. La maestra ha dato molti compiti per } \\
\text { casa. }\end{array}$ & La maestra ha dato compiti per casa. \\
\hline 86. Le rane saltano davanti allo stagno. & + \\
\hline 87. L'atleta corre lontano dallo smog. & + \\
\hline 88. I cani mangiano vicino alla cuccia. & + \\
\hline $\begin{array}{l}\text { 89. Mi piace lo zucchero sulle fette } \\
\text { biscottate. }\end{array}$ & + \\
\hline $\begin{array}{l}\text { 90. Tutti i giorni raggiungo l'ufficio con } \\
\text { l'autobus. }\end{array}$ & + \\
\hline 91. Lo zio si prende cura delle sue nipoti. & NO \\
\hline $\begin{array}{l}\text { 92. Lo straniero compra la casa con le tende } \\
\text { rosse. }\end{array}$ & + \\
\hline $\begin{array}{l}\text { 93. Vedo gli amici milanesi due volte } \\
\text { all'anno. }\end{array}$ & Gli amicimilanesi vedo due volte all'anno. \\
\hline 94. Gli studenti parlano fuori dalle aule. & + \\
\hline 95. Maria dimentica il telefono sul tavolo. & Maria il telefono sul tavolo. \\
\hline 96. Gli operai protestano per le tasse alte. & Per le tasse alte gli operai protestano. \\
\hline 97. Gli operai lavorano vicino alle macchine. & + \\
\hline 98. Marco mi aspetta fuori da casa mia. & Fuori da casa mia mi aspetta Marco. \\
\hline 99. Lo strano signore si siede vicino a Maria. & + \\
\hline Ioo. L'aquilone è volato via col vento. & Col vento l'aquilone è volato via. \\
\hline IOI. Le foglie ingialliscono in autunno. & Le foglie in autunno ingialliscono. \\
\hline
\end{tabular}




\begin{tabular}{|l|l|}
\hline $\begin{array}{l}\text { I02. I marziani sono atterrati nel mio } \\
\text { giardino. }\end{array}$ & Nel mio giardino sono atterrati i marziani. \\
\hline I03. Matteo corre in giardino. & + \\
\hline $\begin{array}{l}\text { I04. Pietro era già stanco dopo la prima } \\
\text { mezz'ora di lavoro. }\end{array}$ & $\begin{array}{l}\text { Dopo la prima mezz'ora di lavoro Pietro era } \\
\text { stanco. }\end{array}$ \\
\hline
\end{tabular}

\section{Sentences with an already scrambled constituent}

\begin{tabular}{|l|l|}
\hline Il ladro lo ha arrestato il commissario. & Lo ha arrestato il commissario. \\
\hline Quei fiori blu sono i miei preferiti. & I fiori blu sono i miei preferiti. \\
\hline Le zucchine mi piacciono cotte al vapore. + & + \\
\hline $\begin{array}{l}\text { Tra i frutti esotici il mango è il mio } \\
\text { preferito. }+\end{array}$ & + \\
\hline Il gelato lo mangio d'estate. + & + \\
\hline Questo progetto lo finirò domani. + & + \\
\hline La macchina l'ho lavata in cortile. + & + \\
\hline Le favole le racconto a mio figlio. + & + \\
\hline La musica leggera nonla sopporto. + & + \\
\hline Di pesci ce ne sono pochi nello stagno. + & + \\
\hline
\end{tabular}

